\title{
Influences of synoptic situation and teleconnections on fog-water collection in the Mediterranean Iberian Peninsula, 2003-2012
}

\author{
David Corell $^{1,2}$ (1) | Maria J. Estrela ${ }^{2} \quad$ Jose A. Valiente ${ }^{1}$ | \\ Cesar Azorin-Molina ${ }^{3,4}$ (i) $\quad$ Deliang Chen ${ }^{3}$ (i)
}

${ }^{1}$ Fundación CEAM (Fundación Centro de Estudios Ambientales del Mediterráneo), Parque Tecnológico, Charles R. Darwin 14, Paterna, Spain

${ }^{2}$ Departamento de Geografía, Universitat de Valencia, Blasco Ibáñez 28, Valencia, Spain

${ }^{3}$ Regional Climate Group, Department of Earth Sciences, University of Gothenburg, Gothenburg, Sweden

${ }^{4}$ Centro de Investigaciones sobre Desertificación, Consejo Superior de Investigaciones Científicas (CIDE-CSIC), Moncada, Spain

\section{Correspondence}

David Corell, Departamento de Geografía, Universitat de Valencia, Blasco Ibáñez 28, 46010 Valencia, Spain.

Email: davidcocu@gmail.com

\section{Funding information}

European Regional Development Fund, Grant/Award Number: CGL2015-64268-R; Spanish Ministerio de Economía y Competitividad

\begin{abstract}
Fog-water collection has been widely analysed for its quantification and potential uses; however, there are few studies assessing the synoptic conditions and largescale teleconnection patterns that affect its occurrence. Focusing on the Mediterranean Iberian Peninsula, this work aims to analyse the synoptic patterns, both at surface level and $850 \mathrm{hPa}$ geopotential height, that most likely to favour fogwater collection, and to quantify the relationship between fog-water collection and the NAOi (North Atlantic Oscillation index), MOi (Mediterranean Oscillation index) as well as WeMOi (Western Mediterranean Oscillation index) teleconnection patterns. For this purpose, daily fog-water observations from a dense network of 23 fog-water collectors located along the Mediterranean Iberian Peninsula for 2003-2012 were analysed in relation to synoptic patterns and the threeteleconnection indices. The major findings are: (a) The most favourable synoptic patterns for fog-water collection are maritime advections carrying humidity from the Mediterranean basin, and cyclonic circulations, whereas anti-cyclonic situations generally led to large number of foggy days with low fog-collection rates. (b) In terms of winds at $850 \mathrm{hPa}$, the most favourable low-level flows for fogwater collection are associated with strong winds $\left(>5.1 \mathrm{~m} \mathrm{~s}^{-1}\right)$ from the Mediterranean. Atlantic winds generally cause a greater number of fog days than Mediterranean winds, with less fog-water collection rates. (c) WeMOi has the greatest influence on fog-water collection, mainly during winter and spring months, with statistically significant negative relationships for most of the stations. MOi also shows a great influence, with a large number of statistically significant negative correlations, mainly during the same months as WeMOi. Lastly, NAOi presented the lowest and no significant negative correlations with fog-water collection.
\end{abstract}

\section{KEYWOR D S}

atmospheric circulation, fog-water, low-level winds, Mediterranean Iberian Peninsula, weather types 


\section{1 | INTRODUCTION}

The Mediterranean Iberian Peninsula is characterized by two contrasting hydrological phenomena, torrential precipitations and long summer drought spells (GarcíaRuiz et al., 2011). Precipitation climate projections for the southern Europe indicate a declining trend in precipitation at the end of the 21st century (IPCC, 2013), which are consistent with previous results that highlight a negative long-term precipitation trend over the last decades (Montón Chiva and Quereda Sala, 1997; Quereda Sala et al., 2000; Millán et al., 2005a, 2005b; Miró et al., 2017). Changes in water resources have direct implications for many socioeconomic and environmental issues in the Mediterranean region (VicenteSerrano, 2004), such as, for example, forest growth (Pasho et al., 2011) and streamflows (Lorenzo-Lacruz et al., 2012), among others.

A local water resource issue that has been least studied to date, but one in which scientific interest is growing in regions where water is scarce, is fog-water collection. In areas subjected to water scarcity such as the Mediterranean region, the hydrological and ecological significance of occult precipitation is crucial, for example, for contributing moisture and nutrients to the vegetation (Nyaga et al., 2015). According to Schemenauer and Cereceda (1994), the Mediterranean Iberian Peninsula fulfils the optimal geographical requirements for harvesting fresh water from fog. In fact, mountain ranges with an elevation above $\sim 500 \mathrm{~m}$ a.s.l. and located near the coast are prone to develop orographic clouds (e.g., Stratocumulus stratiformis clouds) when moist air transported by sea breezes/local winds or synoptic low-level flows is forced upward, forming cloud water droplets by condensation (Azorin-Molina et al., 2011). Previous studies quantified the potential of fog-water collection at several mountainous locations in the Mediterranean Iberian Peninsula (e.g., Millán et al., 1998; Estrela et al., 2008; Valiente et al., 2011). In particular, the Valencian region showed prominent fog-water potential as annual fog-water collection yield exceeded the total annual precipitation per square meter by two- or three-fold (Valiente et al., 2011). Fog-water collection can be harvested with passive systems, known as fog collectors, which require wind to force water droplets to impact and accumulate into the device. A detailed description of the passive fog-water collector used in the present study has been previously described by Estrela et al. (2009).

Orographic and advection fogs have been quantified and studied in relation to their potential uses, with very few studies attempting to assess the synoptic conditions and large-scale teleconnection patterns that favour their collection. For instance, only few studies have assessed atmospheric circulation patterns that are most likely favourable for fog harvesting in general (Houssos et al., 2009, 2012; Van Schalkwyk, 2011; Van Schalkwyk and Dyson, 2013); focused on specific fog collection episodes (Olivier and de Rautenbach, 2002; Marzol, 2005; Fedorova et al., 2008; Fisak et al., 2009; Marzol et al., 2011; Valiente et al., 2011); or analysed the spatiotemporal variability of fog collection (Johnstone and Dawson, 2010). However, to our knowledge, there is a lack of research assessing the influence of synoptic and teleconnection patterns on fog-water collection. This study covers this niche.

The overall objective of the present study is to identify synoptic circulations and commonly used teleconnection patterns that enhance fog-water collection in the Mediterranean Iberian Peninsula. Specifically weather types based on sea level pressure, winds at $850 \mathrm{hPa}$, and the North Atlantic Oscillation (NAO), Western Mediterranean Oscillation (WeMO) and Mediterranean Oscillation (MO) are analysed together with fog-water harvesting records in the Mediterranean Iberian Peninsula.

\section{I STUDY AREA, DATA AND METHODS}

\section{1 | Site description and climate}

The Mediterranean Iberian Peninsula is characterized by coastal mountain ranges that coexist with large coastal plains where the main rivers in the area flow into (Figure 1). Sharp geographic contrasts can be found in the region: large coastal plains in the centre, mainly in the province of Valencia, and other narrower plains to the south and north that alternate with deltas, which are not so relevant, except for the Ebro Delta, with rocky reliefs and cliffs that often exceed $500 \mathrm{~m}$ a.s.l. in elevation and lie near the coast. The mountain ranges that limit the region are: the Bética mountain range to the south, the Iberian mountain range in the centre and west, and the Pyrenees and Catalan Coastal mountain ranges to the north. The study area is limited by the Mediterranean Sea to the east and covers $\sim 60 \mathrm{~km}$ inland of the Iberian Peninsula. Overall, it has a complex orography, with a coastline oriented from SW to NE.

In addition to its typical Mediterranean climate characterized by dry hot summers and mild winters, the Mediterranean Iberian Peninsula also presents a complex precipitation climate. In this regard, the northern sector (Catalonia) contains two different regions: a humid one in the north with precipitations exceeding $700 \mathrm{~mm}$ year $^{-1}$, and a dry one in the south with lower precipitation values. The central sector corresponds to 
F I G URE 1 Elevation map of the Mediterranean Iberian Peninsula showing the location of the 23 fog-water collection stations (black filled triangles). For details of the stations, see Table 1

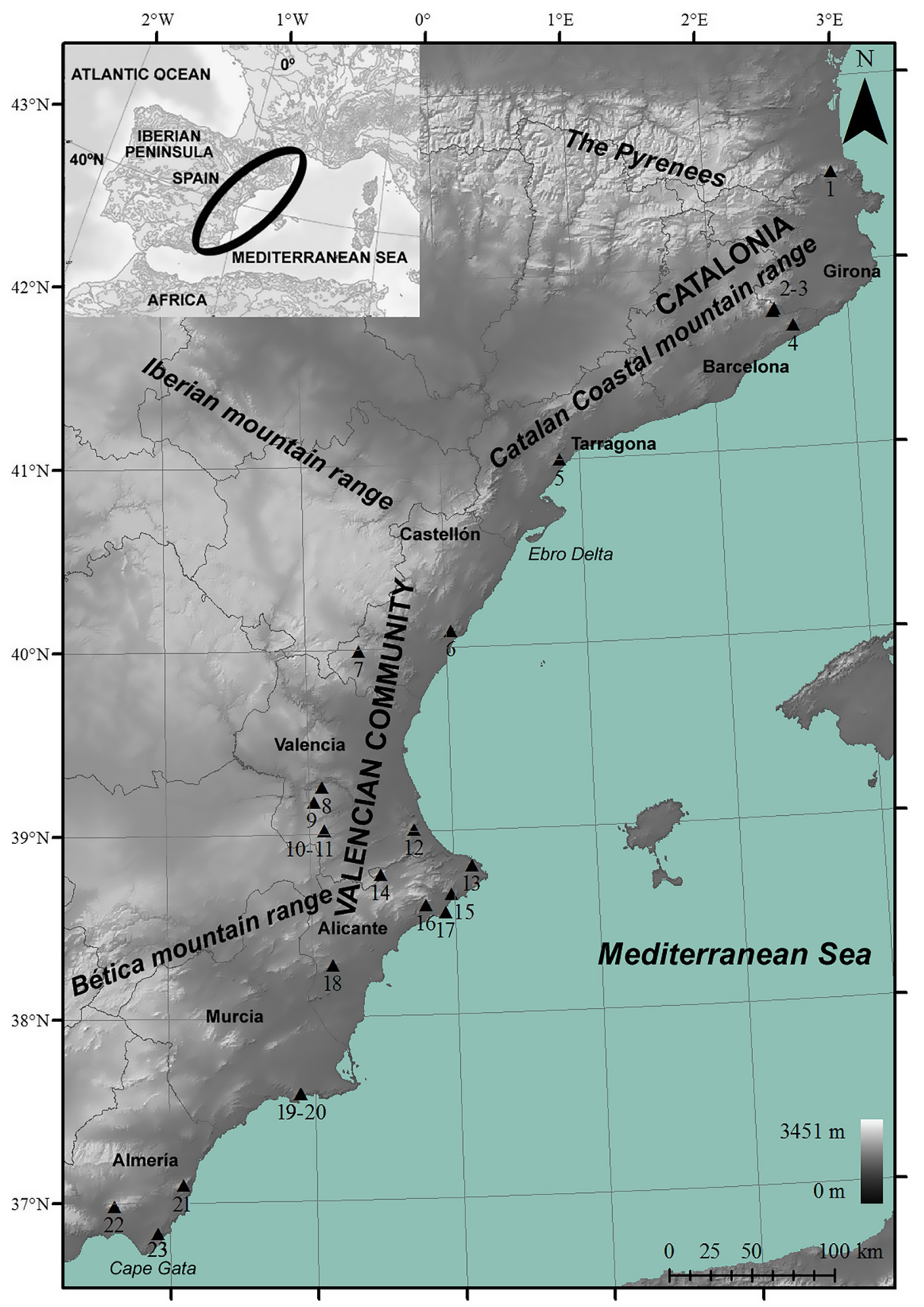

the Valencia and Murcia regions, where the pluviometric regime ranges between $400 \mathrm{~mm} \mathrm{year}^{-1}$ and $600 \mathrm{~mm}$ year $^{-1}$, being therefore classified as arid and semiarid climates (Peñarrocha, 1994). However, orography plays a key role in raising precipitation amounts above $800 \mathrm{~mm}$ year ${ }^{-1}$ over a local humid area south of Valencia. Finally, the southern sector (Almeria region), with its coastline facing the southeast, is the most arid part of the region with annual precipitation below $300 \mathrm{~mm}$ year $^{-1}$ (Peñarrocha, 1994) and with minimum amounts of $125 \mathrm{~mm} \mathrm{year}^{-1}$ and $150 \mathrm{~mm} \mathrm{year}^{-1}$ in the area surrounding Cape Gata; the driest area in continental Europe (Martín-Vide and Olcina Cantos, 2001).

\section{2 | Data and methods}

\subsection{1 | Fog-water collection}

The study makes use of a long-term (10-years; 2003-2012) and dense (23 stations) fog-water collection network along the eastern fringe of the Iberian Peninsula (Table 1). The network covered a length of $1,700 \mathrm{~km}$ from north to south (Figure 1), containing 23 stations distributed in provinces of four Spanish administrative territories (number of deployed stations): (a) Catalonia: Girona (1), Barcelona (3), and Tarragona (1); (b) the Valencian Community: Castellón (2), Valencia (6), 
T A B LE 1 Main characteristics of the fog-water collection stations

\begin{tabular}{|c|c|c|c|c|c|c|}
\hline Code & Station name & Province & Elevation (m a.s.l.) & Dist. to the sea $(\mathrm{km})$ & Start date & End date \\
\hline 1 & Puig Neulós & Gerona & 1,232 & 11 & 27/10/09 & $31 / 12 / 12$ \\
\hline 2 & Montseny Antenas & Barcelona & 1,230 & 21 & $17 / 06 / 10$ & $07 / 02 / 12$ \\
\hline 3 & Montseny Canplá & Barcelona & 832 & 21 & $17 / 06 / 10$ & $07 / 02 / 12$ \\
\hline 4 & Montnegre & Barcelona & 648 & 7 & $18 / 06 / 10$ & $31 / 12 / 12$ \\
\hline 5 & Portella & Tarragona & 707 & 4 & $03 / 11 / 10$ & $31 / 12 / 12$ \\
\hline 6 & Colomer & Castellón & 708 & 5 & $13 / 06 / 08$ & $31 / 12 / 12$ \\
\hline 7 & Casillas & Castellón & 1,150 & 46 & $23 / 03 / 04$ & $31 / 12 / 12$ \\
\hline 8 & Bujete & Valencia & 780 & 52 & $07 / 04 / 11$ & $31 / 12 / 12$ \\
\hline 9 & Cinto Cabra & Valencia & 997 & 59 & $20 / 07 / 10$ & $31 / 12 / 12$ \\
\hline 10 & Machos Nieva & Valencia & 1,025 & 60 & $07 / 06 / 10$ & $31 / 12 / 12$ \\
\hline 11 & Machos & Valencia & 1,025 & 60 & $16 / 11 / 06$ & $31 / 12 / 12$ \\
\hline 12 & Mondúver & Valencia & 843 & 8 & $16 / 07 / 03$ & $31 / 12 / 12$ \\
\hline 13 & Montgó & Alicante & 670 & 3 & $23 / 07 / 03$ & $31 / 12 / 12$ \\
\hline 14 & Mariola & Alicante & 1,193 & 39 & $24 / 06 / 04$ & $31 / 12 / 12$ \\
\hline 15 & Bernia_E & Alicante & 851 & 3 & $13 / 11 / 08$ & $31 / 12 / 12$ \\
\hline 16 & Puig Campana & Alicante & 1,319 & 8 & $30 / 06 / 05$ & 09/02/07 \\
\hline 17 & Sierra Helada & Alicante & 428 & 1 & $04 / 08 / 05$ & $31 / 12 / 12$ \\
\hline 18 & Crevillente & Alicante & 822 & 24 & $01 / 02 / 10$ & $31 / 12 / 12$ \\
\hline 19 & Muela_A & Murcia & 556 & 1 & $23 / 03 / 10$ & $16 / 05 / 12$ \\
\hline 20 & Muela_B & Murcia & 464 & 1 & $23 / 03 / 10$ & $16 / 05 / 12$ \\
\hline 21 & Arraez & Almería & 841 & 5 & $14 / 10 / 10$ & $31 / 12 / 12$ \\
\hline 22 & Alhamilla & Almería & 1,254 & 16 & $02 / 02 / 10$ & $31 / 12 / 12$ \\
\hline 23 & Peñones & Almería & 487 & 3 & $08 / 07 / 10$ & $31 / 12 / 12$ \\
\hline
\end{tabular}

Alicante (6); (c) the Murcia Region: (2); and Andalusia: Almería (3). The first station was set up in July 2003, and the last one stated to be operational in April 2011. All the stations continuously operated from the day they were set up until the end of 2012. Stations' elevations range between $428 \mathrm{~m}$ and 1,319 $\mathrm{m}$ a.s.l. The most inland station of the network is located $60 \mathrm{~km}$ away from the nearest coast. This study uses daily fog-water collected data, that is, fog-water volumes accumulated from 00:00 hr to 23:59 hr (UTC) at each of the 23 experimental stations. Since the setup of the network was gradual and took several years to complete, all the available data for each fog-collection station were selected to obtain the most reliable results. Thus, the whole study period is 2003-2012, but only since April 2011 all stations were operating at the same time. The data period of each station is shown in Table 1 . All data were validated by comparing the records with nearby stations and with other meteorological sensors, as well as through automatic statistical filters. At least $75 \%$ of the data was mandatory to perform the analyses. Relative frequencies of days (in \%) for each of the atmospheric synoptic classifications were calculated as the number of days combining any amount of fog-water collection under such synoptic conditions divided by the total number of days with any fog collection. Moreover, the percentage (in \%) of the fog-water volume collected for a specific atmospheric synoptic type was calculated by summing the collected volumes during that synoptic situation, divided by the total collected volume for the study period. To calculate the fog-water values, a filtering was used to distinguish between rain and fog. This method has been used successfully in previous studies (Estrela et al., 2019) and is based on wind speed and its relationship with rain and fog. The simultaneous record of these three meteorological variables allows the use of a filter that separates fog and rain.

\subsection{2 | The Jenkinson and Collison synoptic classification}

Figure 2 depicts the 16 geographical points whose surface atmospheric pressure was used for the synoptic classification. This grid has been previously used in other climate 
F I G URE 2 The 16 grid-points used for the Jenkinson and Collison synoptic classification

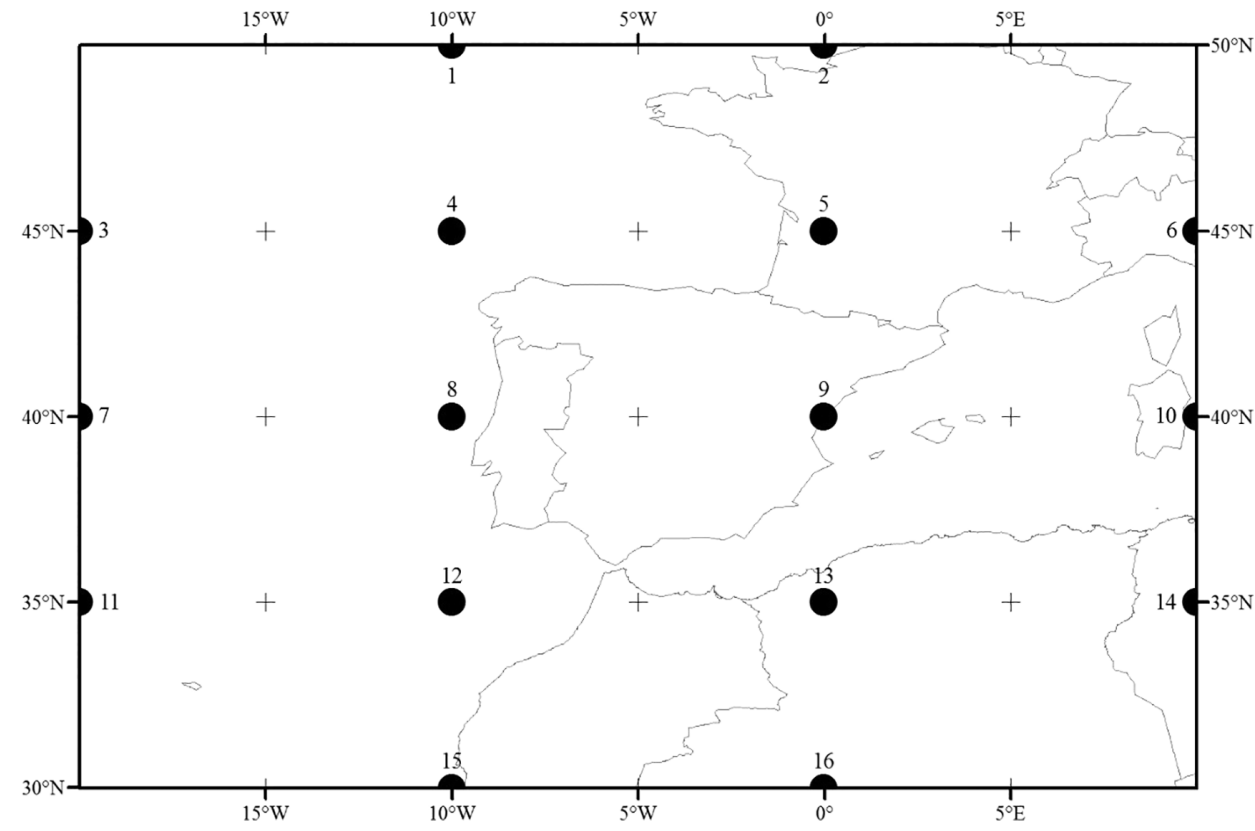

studies for the Iberian Peninsula (e.g., Rasilla et al., 2002; Vicente-Serrano, 2004; Azorin-Molina and LópezBustins, 2008; Azorin-Molina et al., 2011). Points represent the intersection of parallels $30^{\circ}, 35^{\circ}, 40^{\circ}, 45^{\circ}$ and $50^{\circ} \mathrm{N}$ with meridians $20^{\circ} \mathrm{W}, 10^{\circ} \mathrm{W}, 0^{\circ}$ and $10^{\circ} \mathrm{E}$, which include a zone bounded between $30^{\circ}$ and $50^{\circ} \mathrm{N}$, and $20^{\circ} \mathrm{W}$ and $10^{\circ} \mathrm{E}$, centred in the Iberian Peninsula. The daily atmospheric pressure $[p(n)]$ data were obtained from the NCEP/NCAR reanalysis data of the Climate Research Unit, Norwich, UK (http://www.cru.uea.ac. $\mathrm{uk} / \mathrm{cru} / \mathrm{data} / \mathrm{ncep} /$; last accessed July 1, 2019) for 2003-2012.

The JC Method consists of seven equations that calculate geostrophic winds and vorticity conditions in geostrophic units $(\mathrm{hPa})$ to establish the weather situation type on the defined grid. These equations are shown below:

$$
\begin{gathered}
u=0.5(p 12+p 13)-0.5(p 4+p 5), \\
v=1.74[0.25(p 5+2 p 9+p 13)-0.25(p 4+2 p 8+p 12)], \\
V=\left(u^{2}+v^{2}\right)^{1 / 2}, \\
\operatorname{Dir}=\tan ^{-1}(u / v) \\
\xi_{u}=1.07[0.5(p 15+p 16)-0.5(p 8+p 9)] \\
-0.95[0.5(p 8+p 9)-0.5(p 1+p 2)], \\
\xi_{\nu}=1.52[0.25(p 6+2 p 10+p 14)-0.25(p 5+2 p 9+p 13) \\
-0.25(p 4+2 p 8+p 12)+0.25(p 3+2 p 7+p 11)],
\end{gathered}
$$

$$
\xi=\xi_{u}+\xi_{v}
$$

where Equation (1) calculates the zonal component $(\boldsymbol{u})$ of surface geostrophic wind by using the difference in atmospheric pressure between points $12-13\left(35^{\circ} \mathrm{N}\right)$ and 4-5 $\left(45^{\circ} \mathrm{N}\right)$; Equation (2) calculates the meridional component $(\boldsymbol{v})$ of surface geostrophic wind by using the atmospheric pressure gradient between points 5-9-13 $\left(0^{\circ}\right)$ and 4-8-12 $\left(10^{\circ} \mathrm{W}\right)$; Equation (3) calculates the resulting wind speed as the modulus of vector components $\boldsymbol{u}$ and $\boldsymbol{v}(\boldsymbol{V})$ in $\mathrm{m} \mathrm{s}^{-1}$; while Equation (4) calculates the wind direction (Dir) in degrees from North, provided in the eight cardinal directions: N, NE, E, SE, S, SW, W, and NW.

Equation (5) calculates zonal vorticity $\left(\boldsymbol{\xi}_{\boldsymbol{u}}\right)$; Equation (6) calculates meridional vorticity $\left(\boldsymbol{\xi}_{\boldsymbol{v}}\right)$; Equation (7) calculates total vorticity $(\xi)$ as the sum of the zonal and meridional flows.

The constants used in the equations $(1.74 ; 1.07 ; 0.95$ and 1.52) were taken from previous works (Vicente-Serrano, 2004; Azorin-Molina et al., 2011) where they were calculated following the methodology by Dessouky and Jenkinson (1975).

This method identifies 27 weather types, grouped into four categories:

1. Eight directional flow types (N; NE; E; SE; S; SW; W; $\mathrm{NW}$ ), characterized by the coherent wind direction $(|\xi|<V)$.

2. Cyclonic (C) and anti-cyclonic (A) types, related to the atmospheric motion $(|\xi|>2 \mathrm{~V})$. The cyclonic type is obtained for the condition $|\xi|>0$ while the anticyclonic type for the opposite, $|\xi|<0$. 
3. 16 hybrid types, $(V<|\xi|<2 V)$, that depend on $\mathrm{Z}$ and wind direction, being a combination of the two previous types (AN; ANW; AW; ASW; AS; ASE; AE; ANE; $\mathrm{CN}$; CNW; CW; CSW; CS; CSE; CE; CNE).

4. An unclassified synoptic type (U), where $V<6$ and $|\xi|<6$.

The many type $\mathrm{C}$ situations that occur in summer are due to the usual thermal low over the Iberian Peninsula (Azorin-Molina et al., 2011). When we extended the original grid from 9 to 16 surface pressure points, the unclassified synoptic type (U) could be solved, limiting the classification to 26 weather types.

For a further analysis and following the methodology described by Grimalt et al. (2013), the 26 JC weather types were grouped into five other types: the pure advective type (ADV) containing N, NE, E, SE, S, SW, W and NW types; the cyclonic advective type (ADVC) containing $\mathrm{CN}, \mathrm{CNE}, \mathrm{CE}, \mathrm{CSE}, \mathrm{CS}, \mathrm{CSW}, \mathrm{CW}$ and $\mathrm{CNW}$ types; the anti-cyclonic advective type (ADVA) containing AN, ANE, AE, ASE, AS, ASW, AW and ANW types; the pure cyclonic (C) representing the $\mathrm{C}$ weather types and the pure anti-cyclonic (A) matching the A weather type.

\subsection{3 | Low-level synoptic flow regimes}

Wind data at $850 \mathrm{hPa}$ were obtained from the NCEP/ NCAR reanalysis data (http://www.cru.uea.ac.uk/cru/ data/ncep/; last accessed July 1, 2019) for computing lowlevel synoptic flow regimes for 2003-2012. We chose three points: north $\left(\mathrm{P} 1: 42.5^{\circ} \mathrm{N} ; 2.5^{\circ} \mathrm{E}\right)$, centre $\left(\mathrm{P} 2: 40^{\circ} \mathrm{N}\right.$; $0^{\circ}$ ) and south (P3: $37.5^{\circ} \mathrm{N} ; 2.5^{\circ} \mathrm{W}$ ) (Figure 3 ) as representatives of the atmospheric flow dominating the entire study area. The fog-water collection station network was grouped according to their proximity (Figure 1) to the former points: P1, from Puig Neulós to Montnegre (northern sector); P2, from Portella to Sierra Helada (central sector); P3, from Crevillente to Peñones (southern sector).

The synoptic flows were divided into 16 regimes, depending on wind direction and wind speed:

1. Eight wind directions in $45^{\circ}$ intervals, grouped according to this criterion (Figure 4): winds from the Atlantic: SW $\left(202.6^{\circ}-247.5^{\circ}\right), \mathrm{W}\left(247.6^{\circ}-292.5^{\circ}\right)$, NW $\left(292.6^{\circ}-337.5^{\circ}\right)$ and $\mathrm{N}\left(337.5^{\circ}-22.5^{\circ}\right)$; winds from the Mediterranean: NE $\left(22.5^{\circ}-67.5^{\circ}\right)$, E $\left(67.6^{\circ}-112.5^{\circ}\right)$, SE $\left(112.6^{\circ}-157.5^{\circ}\right)$ and $\mathrm{S}\left(157.6^{\circ}-202.5^{\circ}\right)$.

2. Two wind speeds: moderate $\left(0-5.1 \mathrm{~m} \mathrm{~s}^{-1}\right)$ and strong $\left(>5.1 \mathrm{~m} \mathrm{~s}^{-1}\right)$, in accordance with the methodology followed in former works (Gould and Fuelberg, 1996; Connell et al., 2001; Azorin-Molina et al., 2009).

\subsection{4 | Atmospheric circulation modes}

Figure 3 shows the three teleconnection atmospheric indices that were analysed herein:

1. NAO index (NAOi; Jones et al., 1997), which represents the difference between normalized sea level pressure data at $65^{\circ} \mathrm{N}-22.5^{\circ} \mathrm{W}$ (Iceland, Reykjavik) and $35^{\circ} \mathrm{N}-5^{\circ} \mathrm{W}$ (Iberian Peninsula, Gibraltar) using gridded data (http://www.cru.uea.ac.uk/cru/data/ ncep/; last accessed July 1, 2019). The calculated daily

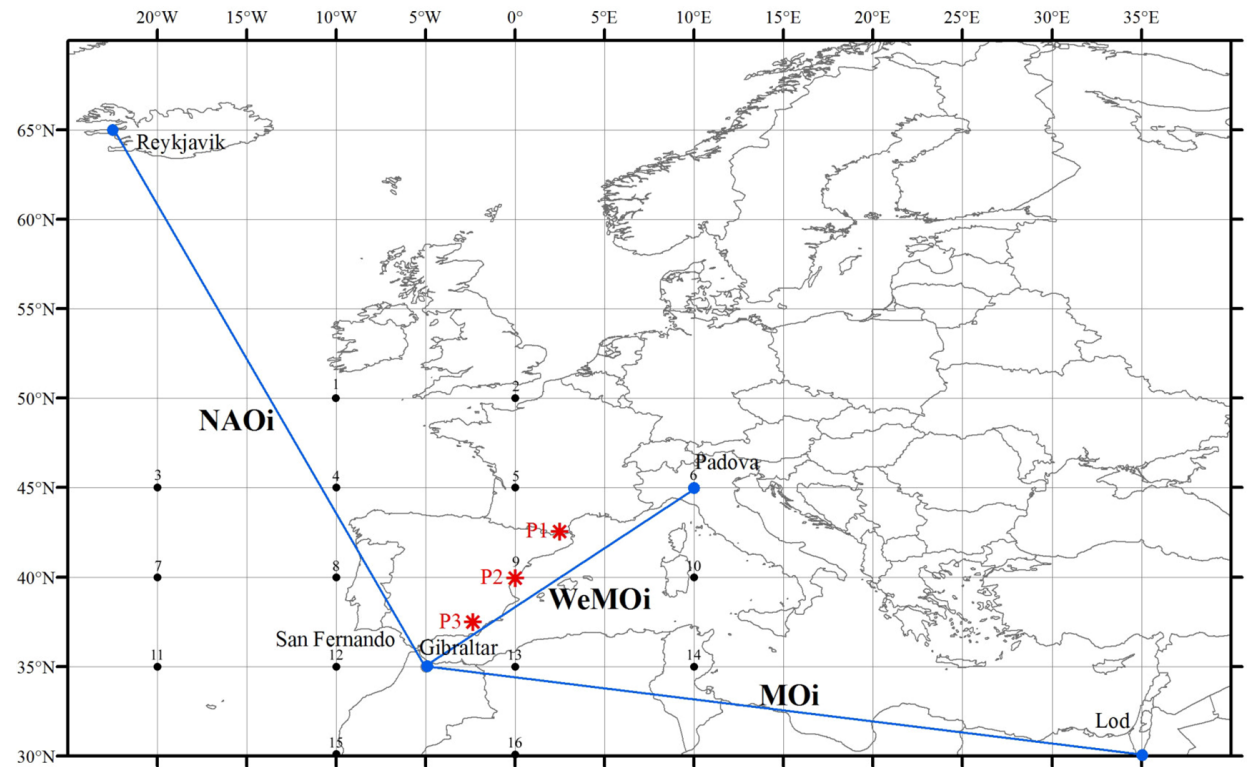

FIGURE 3 Location of the selected grid-points (P1, P2, and P3) for the analysis of wind fields at $850 \mathrm{hPa}$, the surface stations for the calculation of the teleconnection atmospheric indices: NAOi, MOi, and WeMOi and the 16 grid-points used for the Jenkinson and Collison synoptic classification 


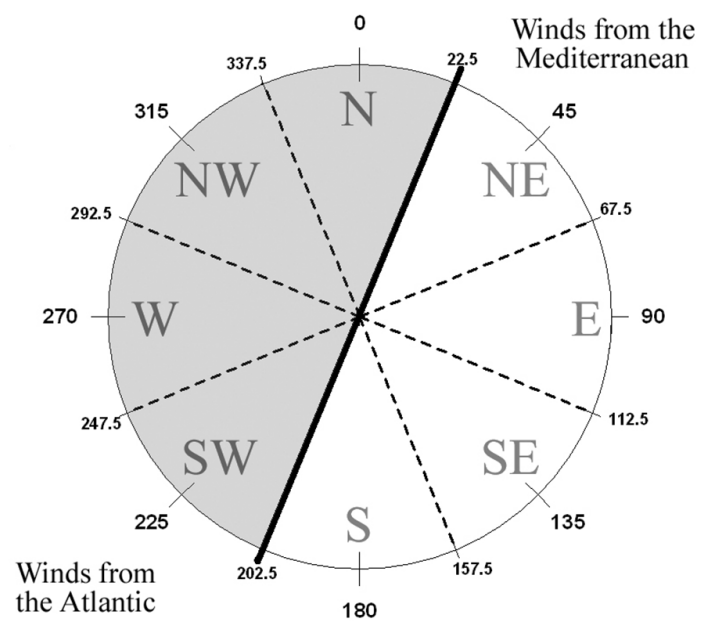

F I G U R E 4 Wind direction classification of the synoptic flows at $850 \mathrm{hPa}$ according to the coastline orientation of the Mediterranean Iberian Peninsula: (i) Atlantic winds, and (ii) Mediterranean winds. These flows are then divided into 16 regimes as a function of wind speed: Light-moderate intensities $\left(\leq 5.14 \mathrm{~m} \mathrm{~s}^{-1}\right)$ and strong wind speeds $\left(>5.14 \mathrm{~m} \mathrm{~s}^{-1}\right)$

NAO index showed a Pearson's correlation coefficient of 0.98 with those obtained with station observation data for 1951-2000.

2. MO index (MOi; Palutikof, 2003) is the difference between normalized sea level pressure data at $35^{\circ} \mathrm{N}-5^{\circ} \mathrm{W}$ (Gibraltar) and $30^{\circ} \mathrm{N}-35^{\circ} \mathrm{E}$ (Lod, east of the Mediterranean basin), with the reanalysis data from http://rda.ucar.edu/datasets/ds010.0/ (Trenberth and Paolino Jr., 1980; last accessed July 1, 2019). The calculated daily MO index data present a Pearson's correlation coefficient of 0.83 with those obtained with station observation data for 1958-2000.

3. WeMO index (WeMOi; Martín-Vide and LópezBustins, 2006), is the difference between normalized sea level pressure data at $35^{\circ} \mathrm{N}-5^{\circ} \mathrm{W}$ (San Fernando) and $45^{\circ} \mathrm{N}-10^{\circ} \mathrm{E}$ (Padova, NE Italy), using reanalysed gridded data (http://www.cru.uea.ac.uk/cru/data/ ncep/; last accessed July 1, 2019). The calculated daily WeMO index data present a Pearson's correlation coefficient of 0.94 with those obtained with station observation data for 1948-2000.

The sign of the Pearson's correlation coefficient (positive or negative) and its statistical significance (at $p<.05, \quad p<.10$ and $p>.10$ ) was calculated between daily fog-water collection data (i.e., 00:00 hr to $23: 59 \mathrm{hr}$, UTC) for each station and the daily values of each teleconnection index, annually and seasonally. Moreover, the number of stations showing positive and negative (and significant or not) correlations was summarized to assess the influence of teleconnection indices on harvested fresh water from fog.

\section{3 | RESULTS}

\section{1 | Fog-water collection disaggregated by the JC synoptic classification}

Looking at the relative frequency of days with any fogwater collection (see line graphs [B] in Figure 5a-c), the advective situations generally stood out in all stations, mainly those that present winds of component $\mathrm{E}$, with a generalized drop for the $\mathrm{S}$ type. The pure $\mathrm{C}$ and $\mathrm{A}$ types, along with the NE, E and SE types, generally provided fog occurrence more regularly. The graphs show a curve that peaks four times, three of which are sharp (one encompasses situations of the NE, E and SE types, and two others containing $\mathrm{C}$ and $\mathrm{A}$ types) and a moderate one (W and NW types). Conversely, the hybrid cyclonic and anti-cyclonic types barely gave fog-water collection days. Mainly, the ADV type explains $50 \%$ of the days with any fog collection in most of the stations, encompassing the $75 \%$ of days when $\mathrm{C}$ and $\mathrm{A}$ types are considered along with the ADV type (Table 2). Hence, the set of cyclonic and anti-cyclonic advective situations contains the remaining $25 \%$ of the days. The encountered types offering the highest frequencies of days with fog-water collection coincide with those weather types found to be the most frequent in the region.

The synoptic situations that provided the largest volumes of fog-water showed large differences among the three latitudinal regions. In the northern sector (Figure 5a), the percentage of the total fog-water collected volumes was higher for the C-type than for the other types. The pure $\mathrm{C}$ days contributed more than $53 \%$ of all the fog-water collected at Montseny Canplá and Montnegre stations, more than 36\% at Portella and Montseny Antenas stations, and approximately 22\% at Puig Neulós station. None of the other synoptic patterns represented more than $10 \%$ of the collected volume at each station. In the central sector of the region (Figure $5 b$ ), the maritime advective situations, such as the NE, E and SE types, became more influential. All these three weather types contributed to more than half of the volume collected in some stations, for example, in Sierra Helada and Bernia_E. In most stations, a peak is shown for the $\mathrm{E}$ type. In the southern sector (Figure 5c), the NE, E and SE types also stood out, with the biggest volumes for the SE situations. The sum of the volumes contributed by the three types represented more than $35 \%$ of the volume obtained for each of the southern stations, except for Peñones where the SW, W 
(a)
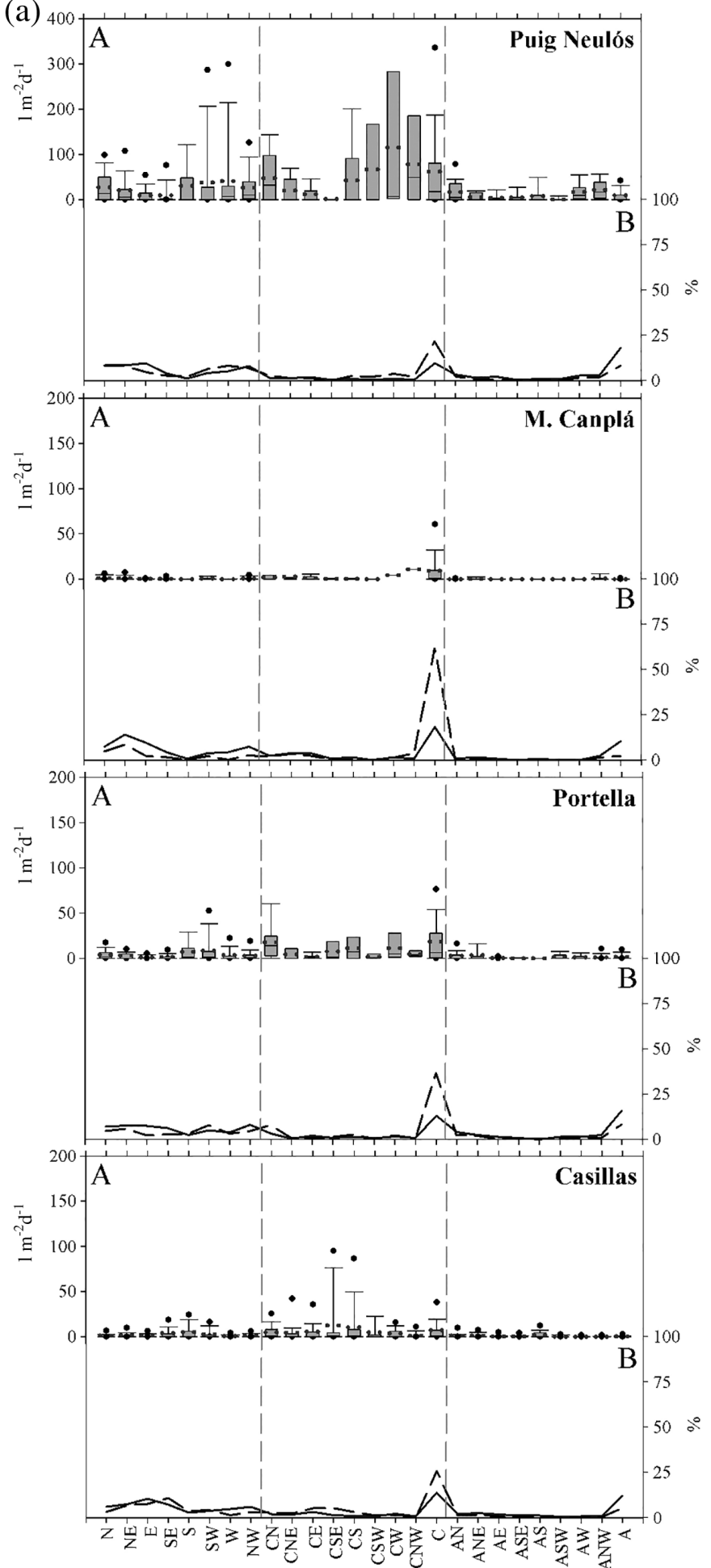
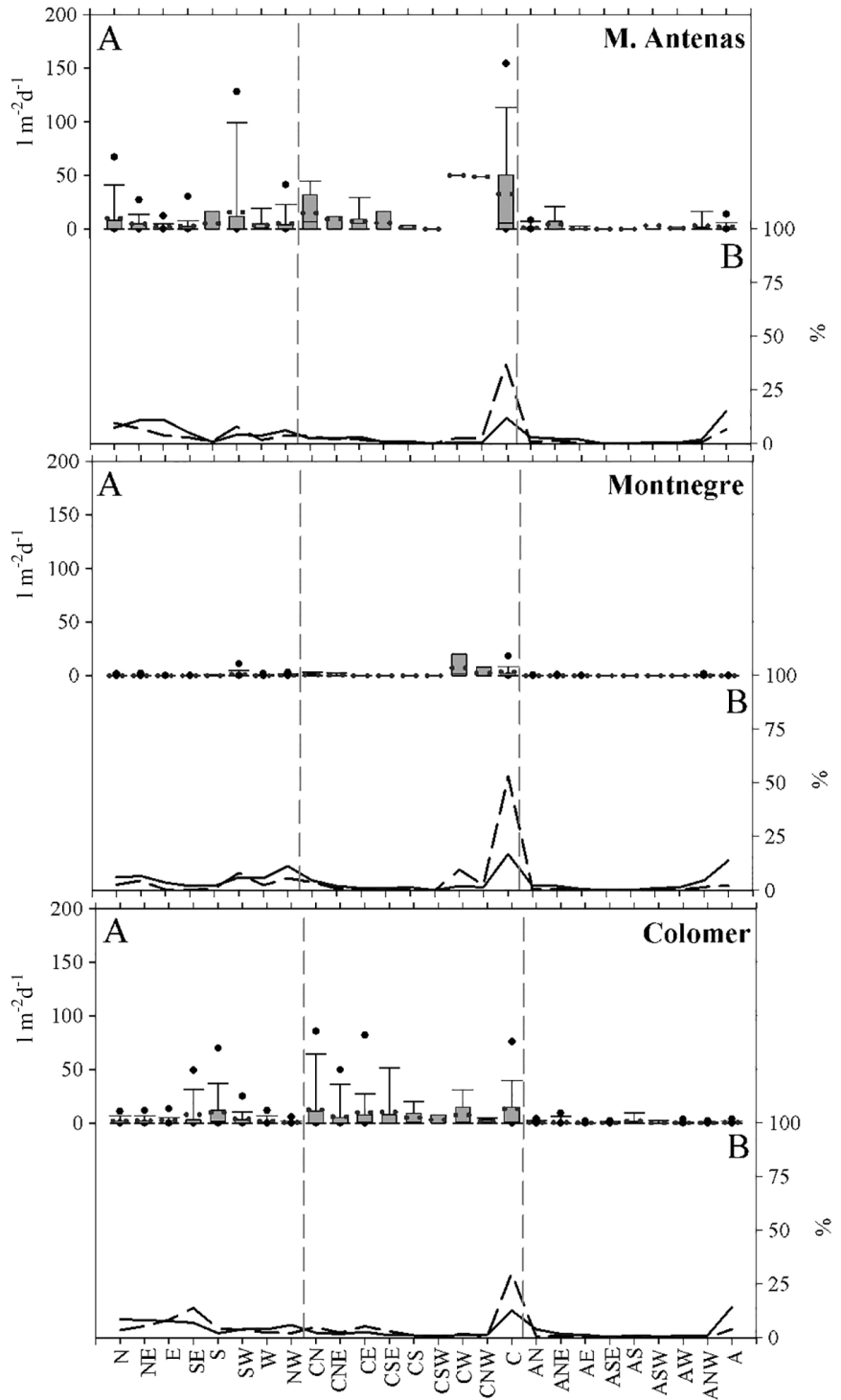

F I G U RE 5 Box chart (a) for the mean (segments), median (double dots), third and first quartiles (box delimiters), 10 and 90 percentiles (whiskers), and 5 and 95 percentiles (bold dots) of the daily fog-water collected volumes; and line graph (b) for both the relative frequency of collection days (solid line) and the percentage of the total collected volumes (dashed line) for each of the $26 \mathrm{JC}$ weather types. Plots are shown for each station in A (northern sector), B (central sector), and C (southern sector). Note that the 26 JC weather types on the $x$-axis have been ordered into three categories: Pure advective situations (N, NE, E, SE, S, SW, W, and NW), cyclonic advective situations (CN, CNE, CE, CSE, CS, CSW, CW, CNW, and C) and anti-cyclonic advective situations (AN, ANE, AE, ASE, AS, ASW, AW, ANW, and A). A (northern sector), B (central sector), and C (southern sector) 
(b)

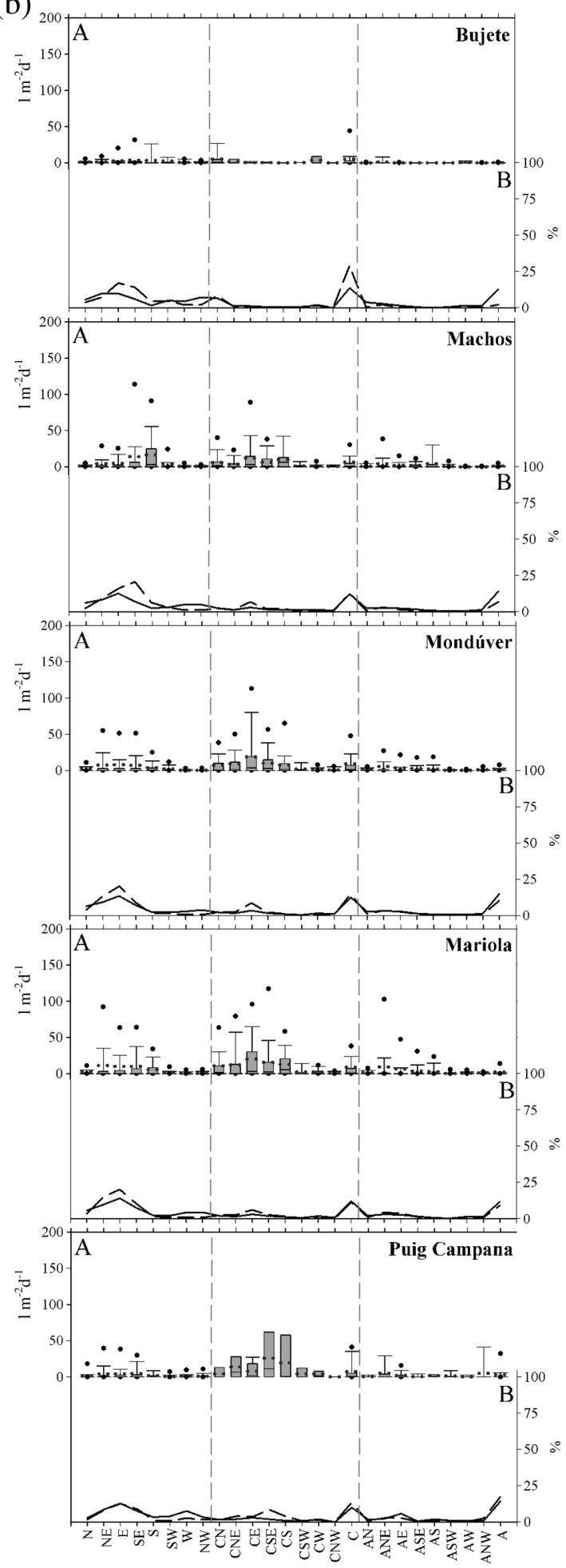

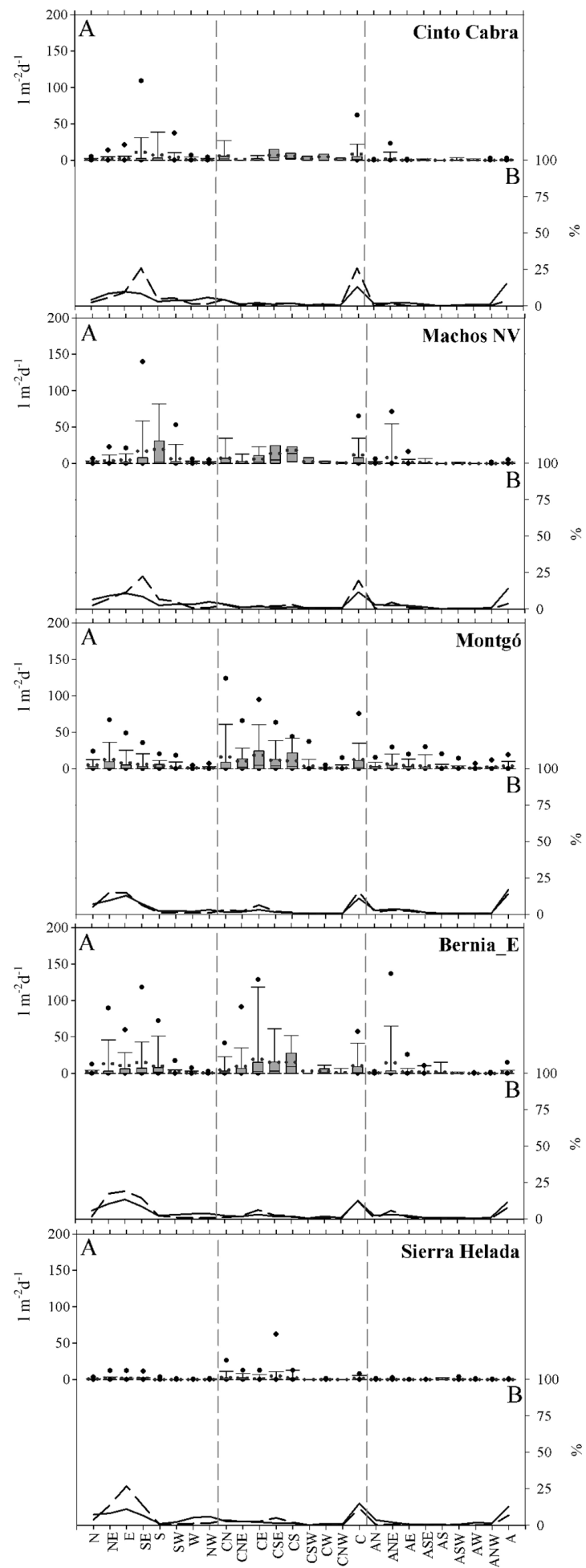

F I G URE 5 (Continued)

and NW types contributed much to the total volumes. In addition, Table 2 shows how the anti-cyclonic situations (i.e., ADVA and A types) contributed to the smallest volumes of water. For instance, in Montseny
Canplá, Montnegre or Bujete, anti-cyclonic situations barely represented $5 \%$ of the total volume. On the contrary, at Puig Campana, Montgó, Mariola and Mondúver, all placed south Valencia and north Alicante 


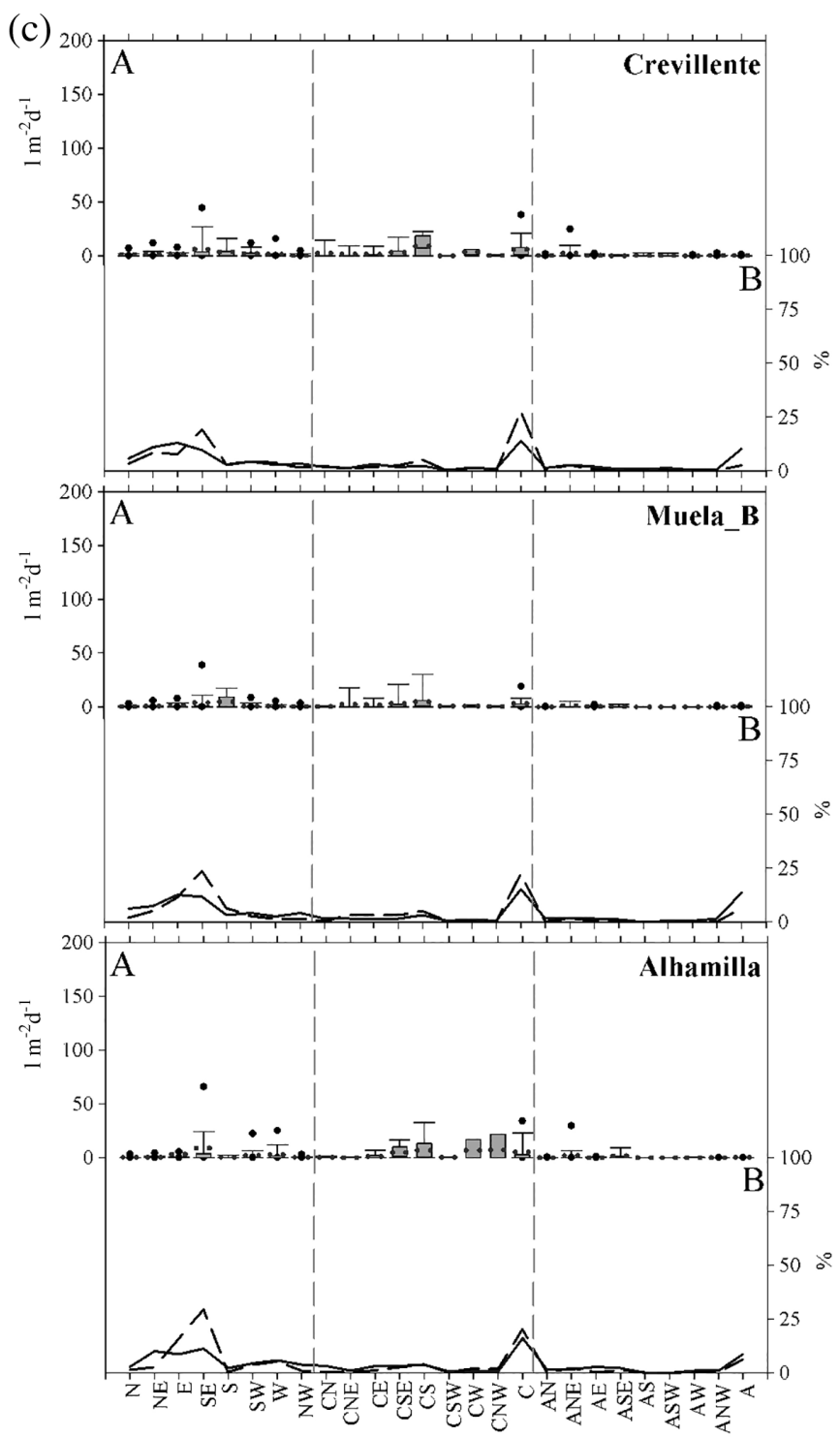

F I G URE 5 (Continued)

provinces, anti-cyclonic situations showed the largest percentages $(\sim 20 \%)$ of collected volumes across the network. At all the other stations, anti-cyclonic days stood out for their low water contributions.

The highest daily fog-water collection volumes were recorded under pure and advective cyclonic types, with some latitudinal differences. In the northern sector (Figure 5a, box chart (A)), the highest means of daily volumes were obtained for cyclonic days with advections from $\mathrm{W}$ to $\mathrm{N}$ (CNW, CW and $\mathrm{CN}$ types) and pure cyclonic days (C type). In the central sector (Figure 5b, box chart (A)), basically in the Puig Campana, Montgó, Mariola and Mondúve, advective weather types associated with maritime flows contributed much to the fog-water collection. Indeed, the cyclonic situations with advections from the Mediterranean basin, that is, CNE, CE and CSE types, showed the highest means of daily volumes.

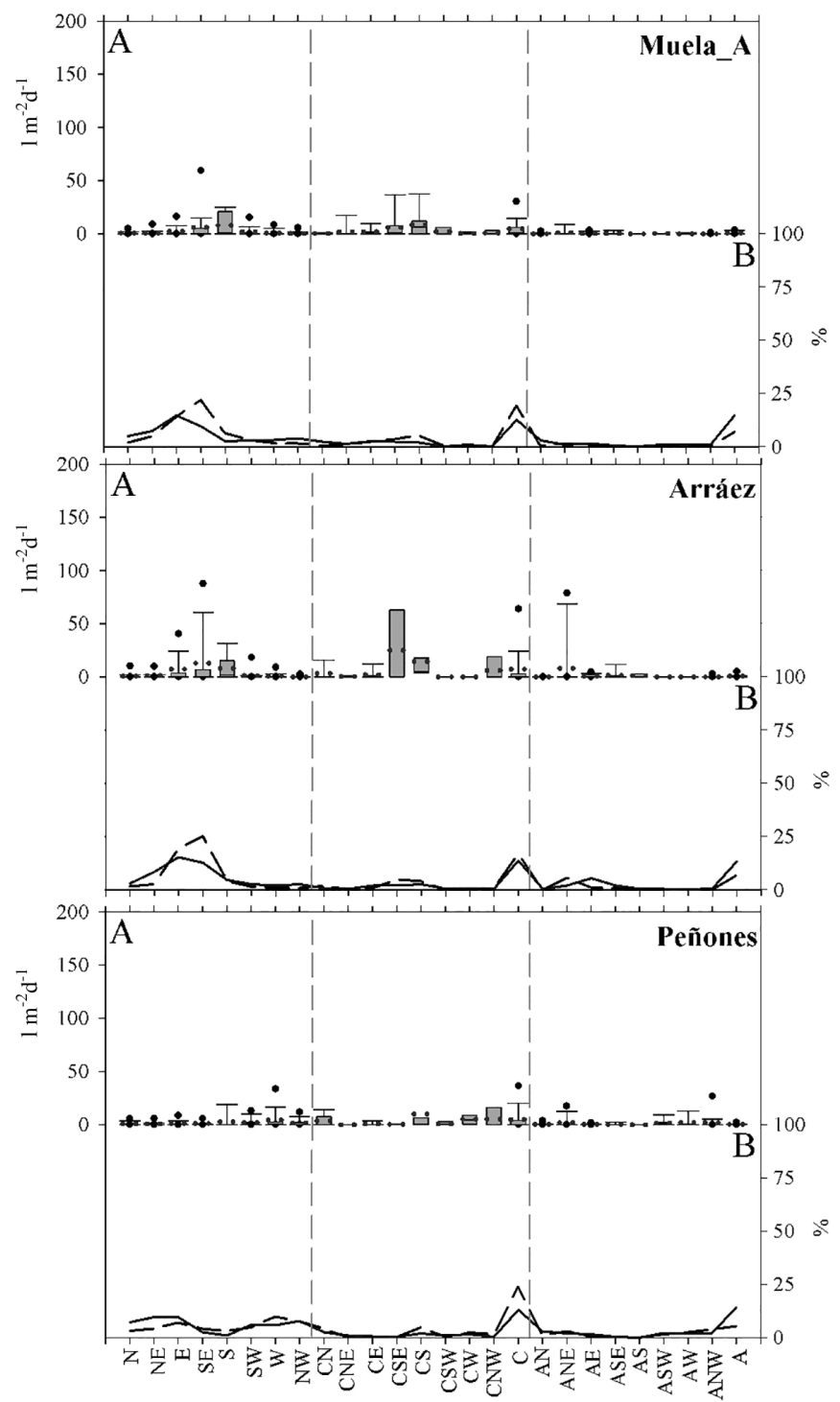

Finally, a similar pattern is shown for the southern sector (Figure 5c, box chart (A)), with the highest means of daily volumes obtained for days driven by cyclonic (CS and CSE) and pure (S and SE) advections.

\section{2 | Fog-water collection disaggregated by synoptic flow at $850 \mathrm{hPa}$}

Given the strong influence with advection identified in the previous section, a synoptic wind at a representative level for moisture transport relevant to fog can be a skilful indicator for fog-water harvesting. The synoptic flows at $850 \mathrm{hPa}$ that produced the largest number of days with fog-water collection (Figure 6, line graph B) were those combining winds from the $\mathrm{W}$, specifically SW, W, NW and N winds. Table 3 shows that low-level 
T A B L E 2 Relative frequency of collection days, percentage of the total collected volume and average of the daily collection volumes, for each of station and for the five group of synoptic situations described in the subsection 2.2.2 (ADV: pure advective type; ADVC: cyclonic advective type; ADVA: anti-cyclonic advective type; C: pure cyclonic type; A: pure anti-cyclonic type)

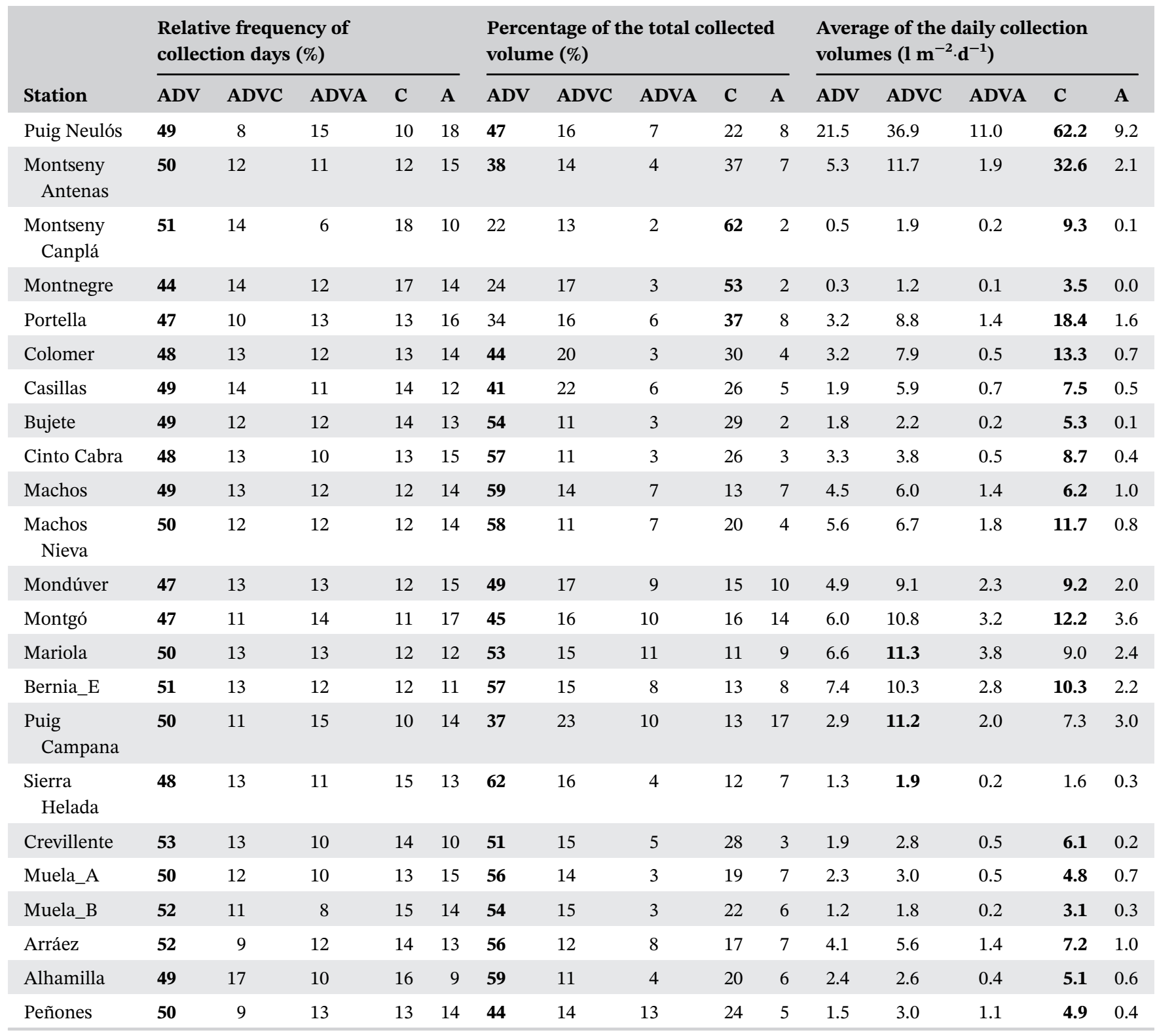

Note: The highest values found for each of the three variables at the different synoptic situations by station are shown in bold.

Atlantic flows produced the largest values for most stations, with the strong winds for the northern sector and strong alternating with moderate winds for the other two regions. In most of the stations of the northern sector, Atlantic flows were responsible for over $75 \%$ of fogwater collection days. Atlantic flows also dominated in the central sector and in Peñones station, with more than $60 \%$ of the collection days. They still represented about $50 \%$ of the collection days for the stations in the southern region. On the contrary, Mediterranean flows only dominated in Arráez station, with $63 \%$ of the fogwater collection days.
In the case of percentages of total volumes, Mediterranean flows dominated, but with slight differences among sectors, producing the largest percentages under strong wind speeds in all cases. Figure 6a (dashed line, line graph [B]) shows the northern region as the sector with the most marked peculiarities, with two northern most stations, along with Portella station, displaying a different behaviour compared to the rest. The percentages at these three locations were larger for strong flows corresponding to SE to SW winds, with Atlantics flows responsible for more than half of the total collected volumes (Table 3). However, in the other stations, synoptic flows that 
(a)
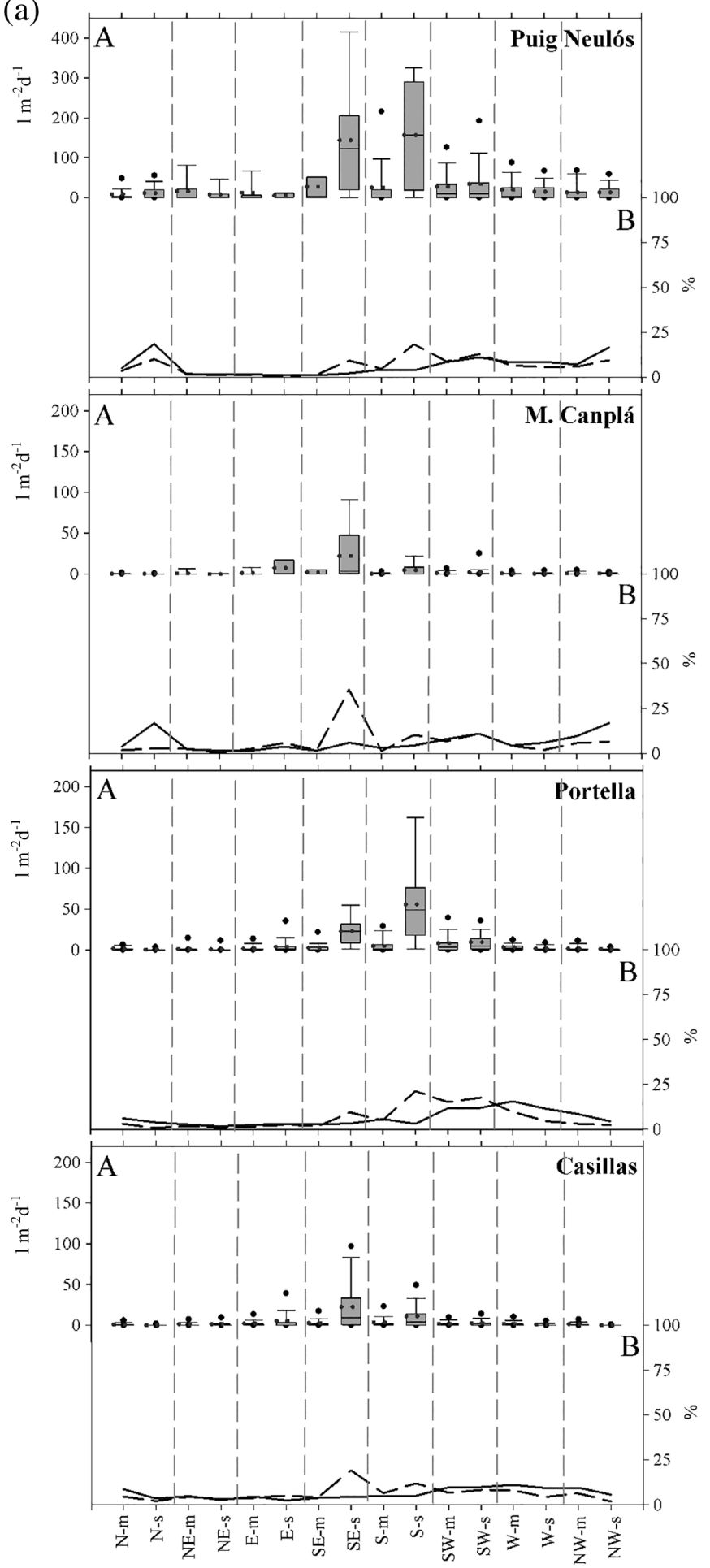

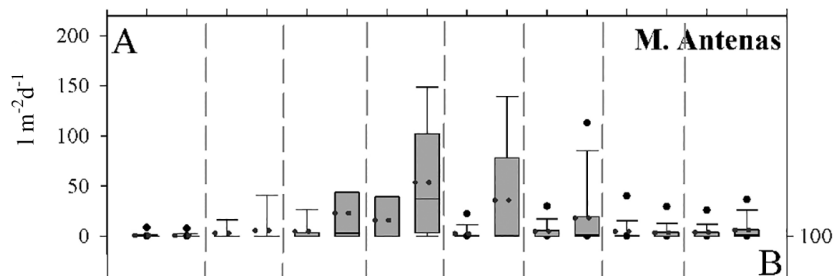

75 50 :
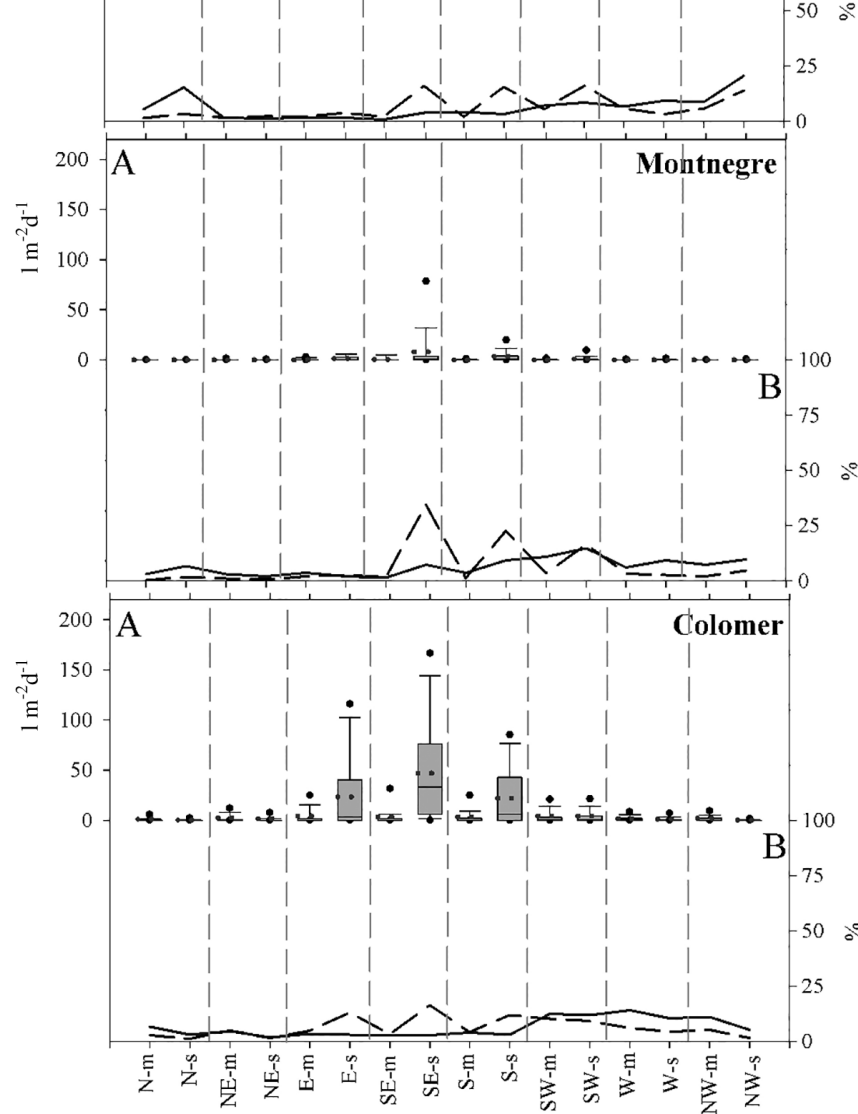

F I G U RE 6 Box chart (a) for the mean (segments), median (double dots), third and first quartiles (box delimiters), 10 and 90 percentiles (whiskers), and 5 and 95 percentiles (bold dots) of the daily fog-water collected volumes; and line graph (b) for both the relative frequency of collection days (solid line) and the percentage of the total collected volumes (dashed line) for each of the 16 synoptic flows at $850 \mathrm{hPa}$ and station. Note that the 16 synoptic flows at $850 \mathrm{hPa}$ on the $x$-axis have been ordered into eight categories: N, NE, E, SE, S, SW, W, and NW winds at two speed ranges, moderate $\left(\mathrm{m} ; \leq 5.14 \mathrm{~m} \mathrm{~s}^{-1}\right)$ and strong $\left(\mathrm{s} ;>5.14 \mathrm{~m} \mathrm{~s}^{-1}\right)$ 
(b)
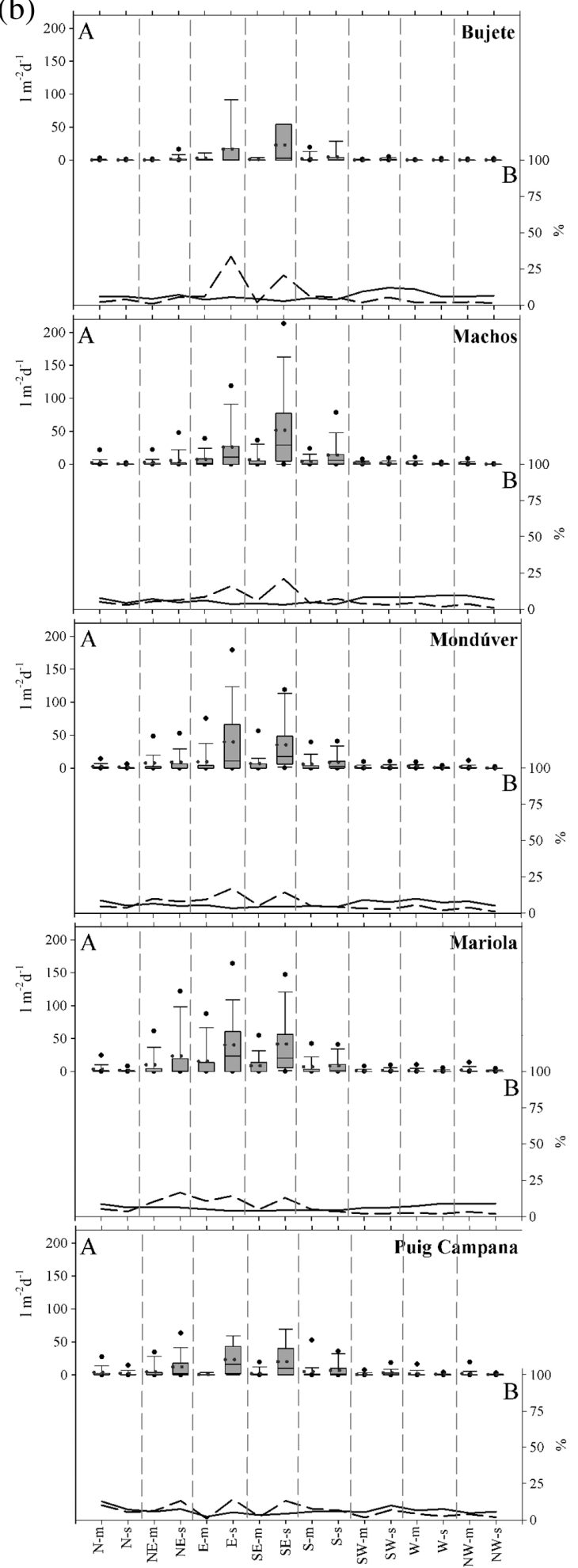

F I G U RE 6 (Continued)

provided the largest percentages of the total collected volumes corresponded to strong SE winds. In some cases, like Montnegre and Montseny Canplá, this wind type depicted roughly $35 \%$ of the total volumes. Table 3 shows how the strong Mediterranean flows are associated with the largest percentages of the total collected volumes, as

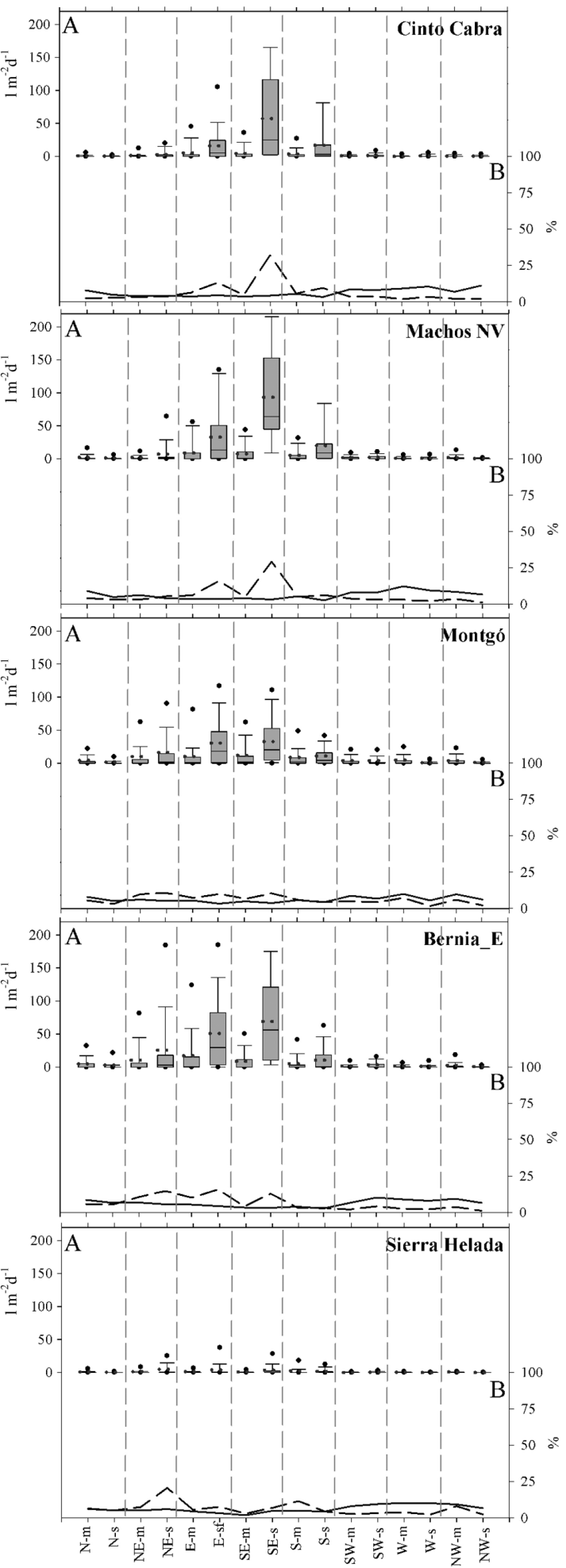

much as $60 \%$ at Montnegre for instance, with all Mediterranean flows contributing much more than the Atlantic ones.

These low-level Mediterranean flows became more relevant for the southern regions, in particular for the central sector. Wind directions that contributed to the 

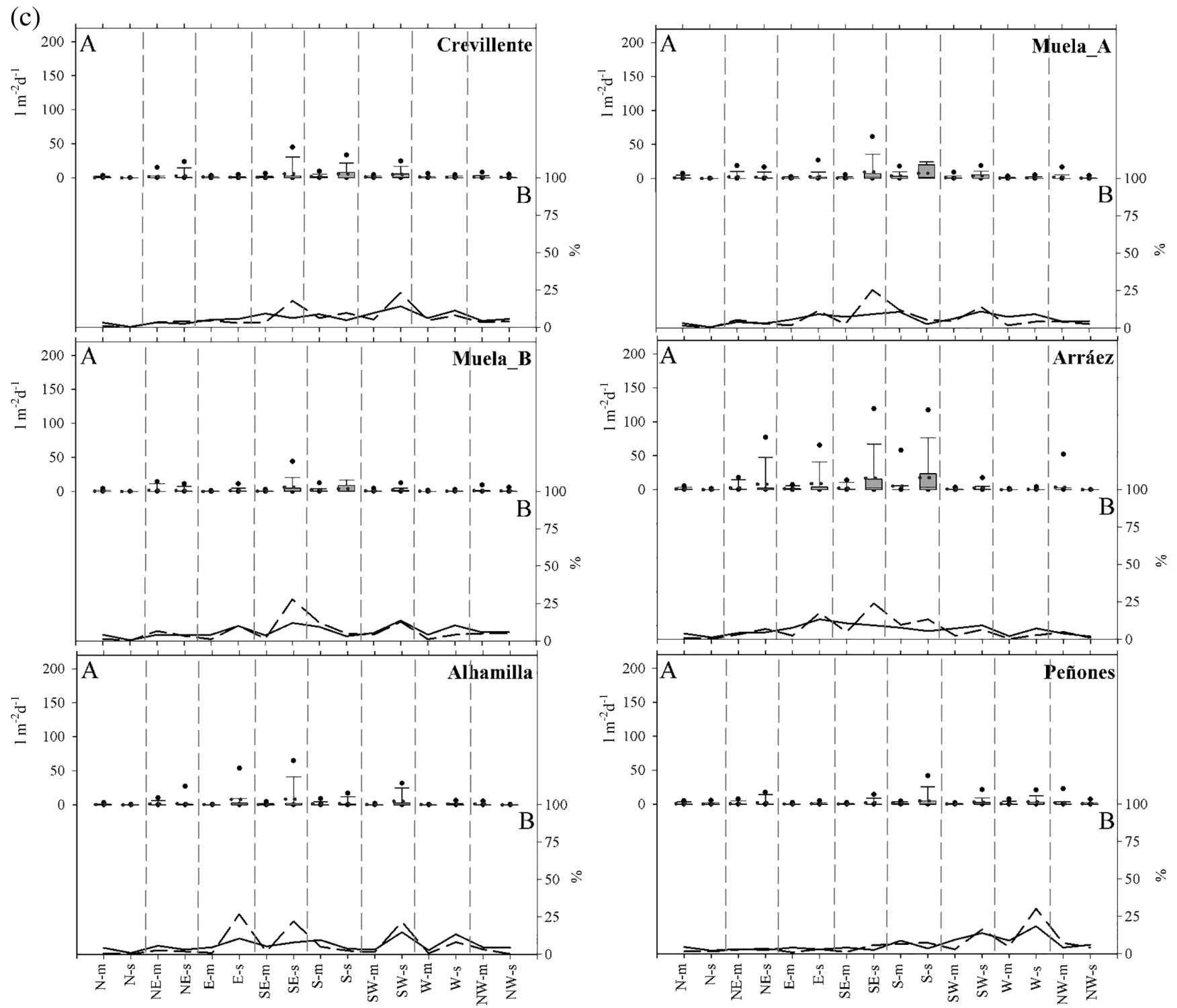

F I G URE 6 (Continued)

highest percentages of the total collected volumes were strong NE, E and SE flows (Figure 6b,c), denoting lowlevel humid advections from the Western Mediterranean basin. Particularly, for Bujete, Cinto Cabra, Machos, Machos Nieva and Mondúver, the most contributing synoptic flows corresponded to strong $\mathrm{E}$ and $\mathrm{SE}$ winds, while other stations, such as Montgó, Mariola, Bernia_E, Puig Campana and Sierra Helada, showed the highest collected volumes under strong NE winds. Mediterranean flows were clearly associated with the largest percentages in all cases, with more than $64 \%$ of the total collected volumes for all stations, even $75 \%$ for some cases.

As a whole, the Mediterranean winds provided more water than the Atlantic ones in all the three regions, except for Peñones and the three stations in the northern sector, where water associated with Atlantic flows represents bigger volumes.

\section{3 | Fog-water collection disaggregated by atmospheric teleconnection indices}

NAOi showed the weakest relationships with fog-water collected volumes across the Mediterranean Iberian Peninsula. Annually, a negative a nonsignificant correlation $(r-.02 ; p>.10)$ was detected (Figure 7$)$. In the northern and southern regions, a weak but significant negative correlation were observed $(p<.05)$, while in the central sector a very weak positive correlation occurred. Significant but weak correlations $(p<.05)$ were found in 13 out of the 23 stations (Table 4). NAOi showed the strongest signal in winter, with negative $r$ values for almost all stations. The highest and significant $(p<.05)$ correlation in winter was found in the southern $(r-.31)$ and northern $(r-.22)$ sectors, with the strongest $r$ value of -.59 in Crevillente. 
T A B L E 3 Relative frequency of collection days, percentage of the total collected volume and average of the daily collection volumes, for each of the stations and for the four wind groups at $850 \mathrm{hPa}$ being defined as follows: Moderate Mediterranean winds (M-m) containing the $\mathrm{NE}, \mathrm{E}, \mathrm{SE}$, and $\mathrm{S}$ flows at speeds $\leq 5.14 \mathrm{~m} \mathrm{~s}^{-1}$, strong Mediterranean winds (M-s) containing the NE, E, SE, and S flows at speeds above $5.14 \mathrm{~m} \mathrm{~s}^{-1}$, moderate Atlantic winds (A-m) containing the SW, W, NW, and $\mathrm{N}$ flows at speeds $\leq 5.14 \mathrm{~m} \mathrm{~s}^{-1}$, and strong Atlantic winds (A-m) containing the SW, W, NW, and $\mathrm{N}$ flows at speeds $>5.14 \mathrm{~m} \mathrm{~s}^{-1}$

\begin{tabular}{|c|c|c|c|c|c|c|c|c|c|c|c|c|}
\hline \multirow[b]{2}{*}{ Station } & \multicolumn{4}{|c|}{$\begin{array}{l}\text { Relative frequency of } \\
\text { collection days (\%) }\end{array}$} & \multicolumn{4}{|c|}{$\begin{array}{l}\text { Percentage of the total collected } \\
\text { volume (\%) }\end{array}$} & \multicolumn{4}{|c|}{$\begin{array}{l}\text { Average of the daily collection } \\
\text { volumes }\left(1 \mathrm{~m}^{-2} \mathrm{~d}^{-1}\right)\end{array}$} \\
\hline & M-m & M-s & A-m & A-s & M-m & M-s & A-m & A-s & M-m & M-s & A-m & A-s \\
\hline Puig Neulós & 8 & 8 & 29 & 55 & 9 & 29 & 25 & 38 & 20.1 & 87.0 & 16.8 & 16.6 \\
\hline Montseny Antenas & 8 & 10 & 28 & 54 & 8 & 37 & 19 & 36 & 4.3 & 29.5 & 3.7 & 5.2 \\
\hline Montseny Canplá & 8 & 15 & 26 & 51 & 8 & 52 & 18 & 22 & 0.8 & 8.2 & 0.6 & 0.5 \\
\hline Portella & 14 & 11 & 42 & 32 & 10 & 34 & 31 & 25 & 2.5 & 14.3 & 3.7 & 2.8 \\
\hline Colomer & 15 & 11 & 44 & 30 & 17 & 43 & 24 & 16 & 3.5 & 18.3 & 2.4 & 1.3 \\
\hline Casillas & 18 & 15 & 39 & 28 & 19 & 39 & 26 & 16 & 2.4 & 8.3 & 1.7 & 0.9 \\
\hline Bujete & 18 & 19 & 32 & 31 & 15 & 65 & 8 & 12 & 1.3 & 9.5 & 0.3 & 0.5 \\
\hline Mondúver & 22 & 17 & 36 & 25 & 30 & 44 & 18 & 9 & 7.9 & 20.1 & 2.4 & 1.0 \\
\hline Montgó & 23 & 17 & 37 & 24 & 30 & 35 & 24 & 11 & 10.1 & 20.9 & 4.2 & 1.6 \\
\hline Mariola & 20 & 19 & 31 & 30 & 31 & 47 & 13 & 9 & 10.6 & 26.9 & 2.3 & 1.3 \\
\hline Bernia_E & 19 & 16 & 34 & 31 & 28 & 46 & 14 & 12 & 10.5 & 34.2 & 2.5 & 1.7 \\
\hline Puig Campana & 17 & 23 & 29 & 30 & 17 & 47 & 20 & 16 & 3.6 & 14.1 & 2.1 & 1.6 \\
\hline Sierra Helada & 16 & 19 & 34 & 31 & 27 & 39 & 21 & 13 & 1.5 & 3.9 & 0.6 & 0.3 \\
\hline Crevillente & 27 & 19 & 23 & 31 & 18 & 34 & 14 & 35 & 1.3 & 3.4 & 0.9 & 1.7 \\
\hline Muela_A & 28 & 25 & 22 & 26 & 22 & 45 & 12 & 21 & 1.6 & 5.1 & 1.0 & 1.3 \\
\hline
\end{tabular}

Note: The highest values found for each of the three variables at the different wind groups by station are shown in bold.

In autumn, NAOi showed the more complex relationships across the region, with a mix of signs, that is, positive for the central and negative for the southern and northern regions (Figure 7). In summer and spring, the NAOi signal still weak, dominating negative correlations with few locations showing significant values $(p<.05)$.

The MOi displayed a stronger influence $(r-.19$; $p<.05)$ on fog-water collected volumes than the NAOi, with a widespread negative correlation pattern for all stations, being 21 out of the 23 stations statistically significant at $p<.05$ (Figure 7 and Table 4). The central sector obtained the weakest Pearson's $r$ value $(-.17)$, while the northern and southern regions showed -.23 and -.26 , respectively (e.g., Montseny Antenas, with an $r$ of -.42 had the strongest correlation). Winter is the season when the strongest negative influence of MOi is noted because 17 out of the 23 stations displayed significant correlations $(p<.05)$, also being all of them negative. Its influence was more marked in the southern region, with $r$ values below -.50 in Crevillente and Alhamilla. Almost the same negative correlation pattern with MOi was shown in spring, particularly in the northern region with $r$ values below -.46 at the five northernmost stations. In autumn, the strongest negative MOi influence was found in the southern region, with a most negative value of $r-.64$ in Muela_A. As for NAOi, MOi showed the weakest relationship in summer, with negative and statistically significant correlations for 7 out of 23 stations $(p<.05)$. 


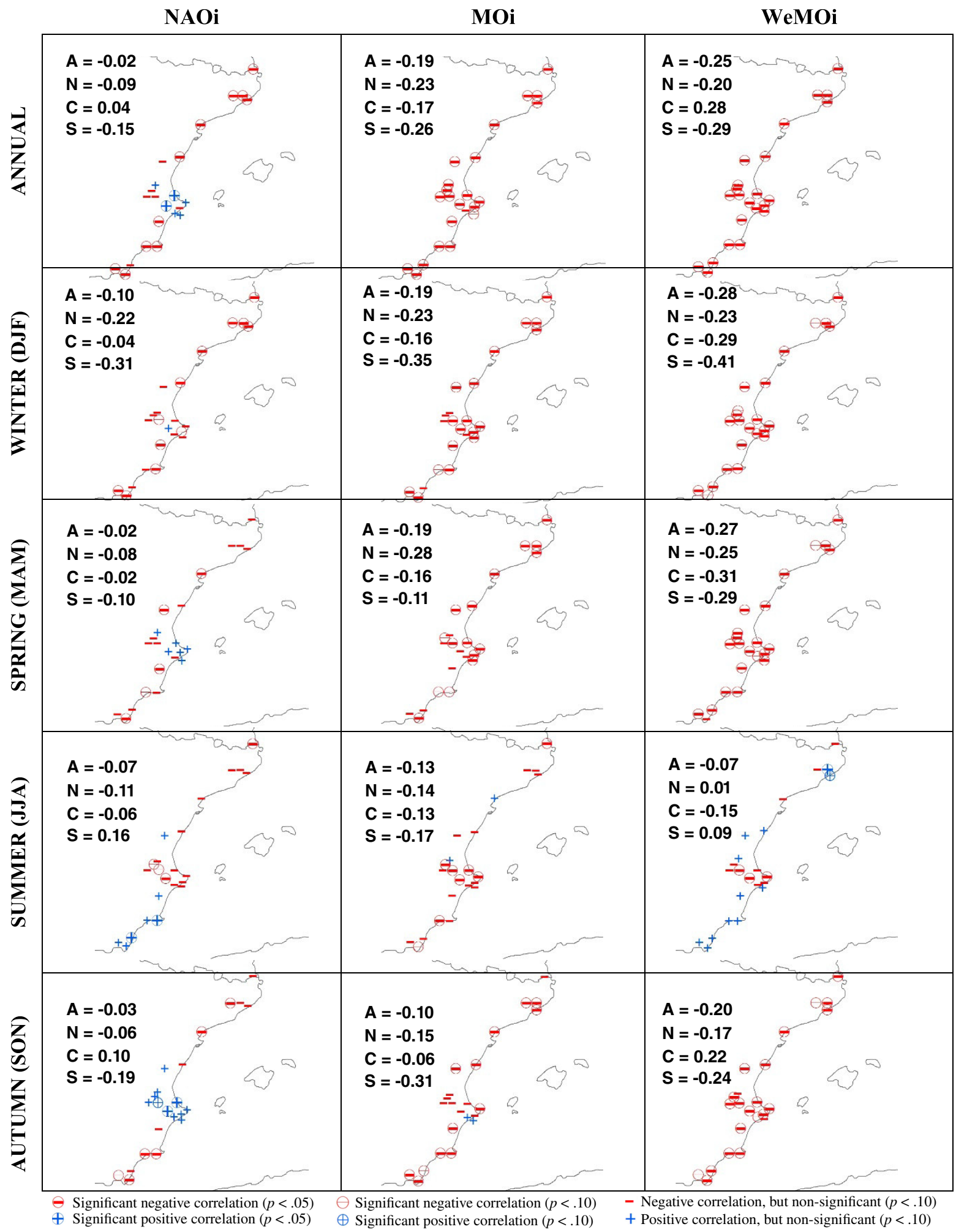

F I G U R E 7 Annual and seasonal station-based correlations (sign and statistical significance) between fog-water collected volumes and NAOi, MOi, and WeMOi on a daily basis. Pearson's correlation coefficients are shown for all the stations (A) and the northern (N), central (c), and southern (S) regions; bold numbers show significant correlations at $p<.05$

Lastly, the WeMOi showed the strongest influence $(r-.25 ; p<.05)$ on fog-water collection among the three indices, with negative and significant values for all stations and regions annually (Figure 7 and Table 4). For instance, negative phases of the WeMOi involve humid ENE, E, ESE and SE advections and, consequently, lowstratiform cloud formation in the Mediterranean mountain ranges of the Iberian Peninsula (Martín-Vide and 
T A B L E 4 Annual and seasonal number of stations showing negative and nonsignificant, negative and significant ( $p<.05)$, positive and nonsignificant, and positive and significant $(p<.05)$ Pearson's correlation values between the daily fog-water collected volumes and the NAOi, MOi, and WeMOi teleconnection indices

\begin{tabular}{|c|c|c|c|c|c|c|c|c|c|c|c|c|}
\hline & \multicolumn{4}{|c|}{ NAOi } & \multicolumn{4}{|c|}{ MOi } & \multicolumn{4}{|c|}{ WeMOi } \\
\hline Annual & 6 & 11 & 4 & 2 & 2 & 21 & 0 & 0 & 0 & 23 & 0 & 0 \\
\hline Winter & 12 & 10 & 1 & 0 & 6 & 17 & 0 & 0 & 3 & 20 & 0 & 0 \\
\hline Spring & 13 & 4 & 6 & 0 & 10 & 13 & 0 & 0 & 3 & 20 & 0 & 0 \\
\hline
\end{tabular}

T A B LE 5 Atmospheric situations as a function of the JC types and synoptic flows at $850 \mathrm{hPa}$ leading to the largest frequencies of collection days combined with the largest percentages of total collected volumes and their associated value ranges for the NAOi, MOi, and WeMOi for each of the network's stations

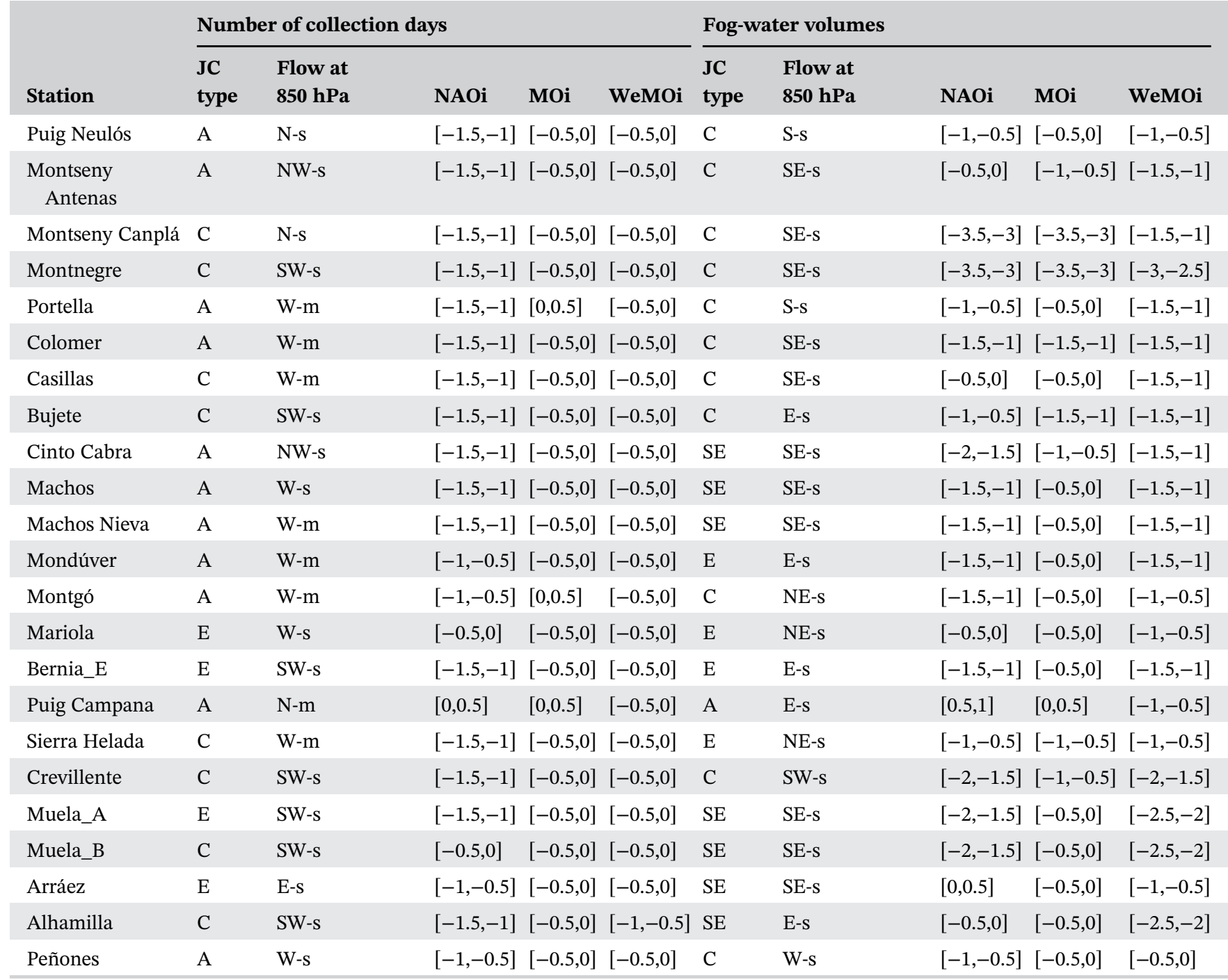

López-Bustins, 2006). This index influenced the most in winter, with a significant correlation of -.28 for the whole region; the highest absolute value for all the studied seasons and indices. All stations also showed negative relationships with WeMOi, being 20 out of 23 statistically significant at $p<.05$, and $r$ values ranged between 
-.58 (Crevillente station) and -.20 (Peñones station). Among the studied regions, the southern sector showed the lowest $r$ value (-.41). Similar correlation patterns were found in spring and autumn. On the contrary, the weakest WeMOi influence was found in summer $(r-.07$ for all stations; $p<.05$ ), with nearly the same number of stations showing positive (12) and negative (11) correlations; only few of them being statistically significant (Table 4).

A summary of the major atmospheric circulations influencing the frequency of fog collection days and fogwater collected volumes for each station across the Mediterranean Iberian Peninsula is shown in Table 5.

\section{4 | DISCUSSION}

To date, no study analysing the synoptic climatology for fog-water collection has been conducted with long-term daily data series for the Mediterranean Iberian Peninsula. Previous studies that have attempted to make the most of fog as a water resource have only been able to analyse the atmospheric conditions for specific collection episodes (e.g., Marzol, 2005; Marzol et al., 2011; Valiente et al., 2011; to name but a few), and have neither evaluated long-term data, nor employed automatic classifications to allow any extrapolation to other regions. Encouraged by successful application of synoptic classifications in the Iberian Peninsula for other meteorological variables, such as precipitation (Martín-Vide and Fernández-Belmonte, 2001; Martín-Vide, 2002) and sea breezes (Azorin-Molina and Chen, 2009; Azorin-Molina et al., 2011), this study attempts, for the first, to evaluate the influence of the synoptic conditions for the fog-water collection.

One of the most outstanding results is that both maritime advections, carrying humidity from the Mediterranean sea and cyclonic situations, are the most favourable conditions near surface for fog-water collection. Additionally, the most favourable low-level flow directions varied as a function of elevation, but most importantly due to the coastline orientation (Azorin-Molina et al., 2009). Anti-cyclonic circulations generally led to many foggy days, but also to low collection rates. Some studies carried out in the western Mediterranean basin confirm part of these results (e.g., Valiente et al., 2011): humid air of Mediterranean origin is needed in the form of maritime advections for fog-water collection to occur. Moreover, in Estrela et al. (2008), the cyclonic situations were already pointed out as the major contributors in fogwater collection when predominant wind directions carrying fog were analysed in mountainous inland locations of the Valencian region.
The analysis of low-level wind fields at $850 \mathrm{hPa}$ was used here to account for the prevailing atmospheric conditions above surface level that are relevant for fog water collection. Some previous studies analysed wind speeds and directions at low levels that determine different observed cloud patterns (Combs et al., 2001; Connell et al., 2001), proving that both variables play a key role for the development and features of local winds and sea breezes (Estoque, 1962; Blanchard and Lopez, 1984; Azorin-Molina and Chen, 2009), and also in the occurrence of low clouds in the Southeast Iberain Peninsula (Azorin-Molina et al., 2009). The most favourable fogwater collection conditions at the $850 \mathrm{hPa}$ synoptic scale found corresponded to strong $\left(>5.14 \mathrm{~m} \mathrm{~s}^{-1}\right.$ ) Mediterranean winds. On the contrary, Atlantic winds led to generally more foggy days than Mediterranean ones, but they generated less collected water volumes.

Results obtained here in relation to atmospheric teleconnection indices present a novel degree as long as no studies have been found that correlate teleconnection patterns with fog-water collection volumes. Other studies have demonstrated relationships between teleconnections indices and different meteorological conditions in the Iberian Peninsula, such as sea breezes (Azorin-Molina and López-Bustins, 2008; Azorin-Molina et al., 2009), near-surface winds (Azorin-Molina et al., 2014), snow accumulation and avalanches (Garcia et al., 2010; Revuelto et al., 2012), rainfall (Martín-Vide and López-Bustins, 2006; Ramis et al., 2013), sea water level (Tsimplis and Shaw, 2010), droughts (Muhlbauer et al., 2013), and air temperature (Fernández-Montes and Rodrigo, 2012). A large part of the Iberian Peninsula climate variability can be explained by means of the NAOi, MOi and WeMOi (Palutikof, 2003; Martín-Vide and López-Bustins, 2006; Vicente-Serrano and Trigo, 2011). In this study, the analysis of the three teleconnection indices (NAOi, MOi and WeMOi) showed that WeMOi most strongly influence fog collection (mainly in winter and spring months). MOi performed similarly, and had a negative and statistically significant influence on all the analysed stations. However, NAOi showed the lowest correlation. Indeed, its behaviour is similar to that reported by Martín-Vide and Fernández-Belmonte (2001) in their study on peninsular precipitation. As with rainfall, the strongest influence of local processes on fog formation led to the weak influence of the NAOi in summer and spring.

Although results obtained here are encouraging, longer fog collection series are still necessary to reach more robust conclusions, as short time series could mask any extraordinary situation. In the context of climate change, with projections indicating an important rainfall depletion (IPCC, 2013, 2014), this type of studies become more 
important in arid and semi-arid environments where water is a scarce resource as the Mediterranean Basin (Vicente-Serrano et al., 2015). Future fog-water collection projects can benefit from the results obtained here, improving collection efficiencies of the implanted systems attending to the particular synoptic conditions of the region. In turn, studies on synoptic conditions may allow for the improvement of certain activities and more accurate future projections. As examples, studies conducted in South Africa (Van Heerden et al., 2010; Van Schalkwyk and Dyson, 2013) on fog occurrence have allowed to improve airport activities at Cape Town. Other studies in the northwestern Greece (Houssos et al., 2009, 2012) have also emphasized the importance of previous synoptic analyses as a prerequisite to the installation of passive collecting systems when maximum collecting efficiencies are sought.

\section{5 | CONCLUSION}

In short, our results reveal that pure anti-cyclonic situations (type-A) at surface level reveal more importance for frequency of fog occurrence than for the collected water volumes. Although these situations appear quite frequently, they tend to provide small quantities of water. On the other hand, advections from the sea (types NE, E, $\mathrm{SE}$, and even $\mathrm{S}$ in some cases) and pure cyclonic situations (type-C) bring humidity inland, favouring low cloud formation and the possibility to collect higher amount of fog-water, although their occurrence frequencies are lower.

In terms of the synoptic flows at $850 \mathrm{hPa}$, and without providing the peculiarities of each station, the largest number of days with fog collection take place in Atlantic winds situations (N, NW, W and SW), irrespectively of wind speed. However, the biggest water volumes are collected under the influence of high-speed Mediterranean flows, and the same can be said of the highest collection averages.

Of the three teleconnection indices analysed, NAOi is the one with the weakest correlation, with a practically null value $(r=-.02)$ and nonsignificant for the annual. MOi has a negative correlation in the annual computation $(r=-.19)$, showing a greater influence than NAOi in the collection of fog-water. Therefore, WeMOi is the most influential on water collection of the three indices analysed. The negative WeMOi values imply advections from ENE, E, ESE and SE on the Mediterranean Iberian Peninsula (Martín-Vide and López-Bustins, 2006), representing a contribution of humidity to the atmosphere and, therefore, favouring the conditions for the formation of low clouds that give rise to advection fogs.

\section{ACKNOWLEDGMENTS}

This study has been funded by the Spanish Ministerio de Economía y Competitividad and the European Regional Development Fund (FEDER) through the project CGL2015-64268-R (MINECO/FEDER, UE). For this study, the Fundación CEAM was partly supported by Generalitat Valenciana and research projects "DESESTRES" PROMETEOII/2014/038 (Consellería de Cultura) and "VERSUS" CGL2015-67466-R (MINECO/FEDER). Tinghai Ou is acknowledged for assisting the computation of the weather classification. The authors wish to acknowledge the anonymous reviewers for their detailed and helpful comments to the original manuscript.

\section{ORCID}

David Corell (10) https://orcid.org/0000-0002-1826-8625 Cesar Azorin-Molina (iD https://orcid.org/0000-0001-59137026

Deliang Chen (1) https://orcid.org/0000-0003-0288-5618

\section{REFERENCES}

Azorin-Molina, C. and Chen, D. (2009) A climatological study of the influence of synoptic-scale flows on sea breeze evolution in the bay of Alicante (Spain). Theoretical and Applied Climatology, 96(3-4), 249-260.

Azorin-Molina, C., Connell, B.H. and Baena-Calatrava, R. (2009) Sea breeze convergence zones from AVHRR over the Iberian Mediterranean area and the isle of Mallorca (Spain). Journal of Applied Meteorology and Climatology, 48(10), 2069-2085.

Azorin-Molina, C. and López-Bustins, J.A. (2008) An automated sea breeze selection technique based on regional sea-level pressure difference: WeMOi. International Journal of Climatology, 28 (12), 1681-1692.

Azorin-Molina, C., Tijm, S., Chen, D. and Baldi, M. (2011) A multiyear study of sea breezes in a Mediterranean coastal site: Alicante (Spain). International Journal of Climatology, 31(3), 468-486.

Azorin-Molina, C., Vicente, S.M., McVicar, T.R., Jerez, S., SanchezLorenzo, A., López-Moreno, J.I., Revuelto, J., Trigo, R.M., López-Bustins, J.A. and Espirito-Santo, F. (2014) Homogenization and assessment of observed near-surface wind speed trends over Spain and Portugal, 1961-2011. Journal of Climate, 27, 3692-3712.

Blanchard, D.O. and Lopez, R.E. (1984) Variability of the convective field pattern in South Florida, and its relationship to the synoptic flow. NOAA TEch. Memo. ERL ESG-4, Boulder, CO. 77 pp.

Combs, C.L., Stuart, N.A., DeMaria, M. and Vonder Haar, T.H. (2001) Wind regime GOES cloud cover composites for the Wakefield, VA county warning area. 11th Conference on Satellite Meteorology and Oceanography, Madison. pp. 165-167.

Connell, B.H., Gould, K.J. and Purdom, J.F.W. (2001) Highresolution GOES-8 visible and infrared cloud frequency composites over northern Florida during the summers 1996-99. Weather and Forecasting, 16(6), 713-724.

Dessouky, T.M. and Jenkinson, A.F. (1975) An objective daily catalogue of surface pressure, flow and vorticity indices for egypt 
and its use in monthly rainfall forecasting. Synoptic Climatology Branch Memorandum 46. Meteorological Office: Bracknell.

Estoque, M.A. (1962) The sea breeze as a function of the prevailing synoptic situation. Journal of the Atmospheric Sciences, 19(3), 244-250.

Estrela, M.J., Corell, D., Valiente, J.A., Azorin-Molina, C. and Chen, D. (2019) Spatio-temporal variability of fog-water collection in the eastern IberianPeninsula: 2003-2012. Atmospheric Research, 226, 87-101.

Estrela, M.J., Valiente, J.A., Corell, D., Fuentes, D. and Valdecantos, D. (2009) Prospective use of collected fog water in the restoration of degraded burned areas under dry Mediterranean conditions. Agricultural and Forest Meteorology, 149, 1896-1906.

Estrela, M.J., Valiente, J.A., Corell, D. and Millán, M. (2008) Fog collection in the western Mediterranean basin (Valencia region, Spain). Atmospheric Research, 87, 324-337.

Fedorova, N., Levit, V. and Fedorov, D. (2008) Fog and stratus formation on the coast of Brazil. Atmospheric Research, 87, 268-278.

Fernández-Montes, S. and Rodrigo, F.S. (2012) Trends in seasonal indices of daily temperature extremes in the Iberian Peninsula, 1929-2005. International Journal of Climatology, 32(15), 2320-2332.

Fisak, F., Tesar, M. and Fottova, D. (2009) Pollutant concentrations in the Rimeand fog water at the Milesovka observatory. Water, Air, and Soil Pollution, 196(1-4), 273-285.

Garcia, C., Peña, J.C., Martí, G., Oller, P. and Martínez, P. (2010) WeMOI and NAOi influence on major avalanche activity in the eastern Pyrenees. Cold Regions Science and Technology, 64(2), 137-145.

García-Ruiz, J.M., López-Moreno, J.I., Vicente-Serrano, S., LasantaMartínez, T. and Beguería, S. (2011) Mediterranean water resources in a global change scenario. Earth Science Reviews, 105, 121-139.

Gould, K.J. and Fuelberg, H.E. (1996) The use of Goes-8 imagery and RAMSDIS to develop a sea breeze climatology over the Florida panhandle. 8th Conference on Satellite Meteorology and Oceanography. Atlanta: American Meteorological Society. pp. 100-104.

Grimalt, M., Tomás, M., Alomar, G., Martín-Vide, J. and MorenoGarcía, M.C. (2013) Determination of the Jenkinson and Collison's weather types for the western Mediterranean basin over the 1948-2009 period. Temporal analysis. Atmosfera, 26(1), 75-94.

Houssos, E.E., Lolis, C.J. and Bartzokas, A. (2009) The main characteristics of atmospheric circulation associated with fog in Greece. Natural Hazards and Earth System Science, 9(6), 1857-1869.

Houssos, E.E., Lolis, C.J., Gkikas, A., Hatzianastassiou, N. and Bartzokas, A. (2012) On the atmospheric circulation characteristics associated with fog in Ioannina, North-Western Greece. International Journal of Climatology, 32(12), 1847-1862.

IPCC. (2013) In: Stocker, T.F., Qin, D., Plattner, G.-K., Tignor, M., Allen, S.K., Boschung, J., Nauels, A., Xia, Y., Bex, V. and Midgley, P.M. (Eds.) Climate Change 2013: The Physical Science Basis. Contribution of Working Group I to the Fifth Assessment Report of the Intergovernmental Panel on Climate Change. Cambridge, United Kingdom and New York, USA: Cambridge University Press, p. 1535.
IPCC. (2014) In: Pachauri, R.K. and Meyer, L.A. (Eds.) Climate Change 2014: Synthesis Report. Contribution of Working Groups I, II, and III to the Fitht Assessment Report of the Intergovernmental Panel on Climate Change. Geneva, Switzerland: Tech. rep. IPCC.

Johnstone, J.A. and Dawson, T.E. (2010) Climatic context and ecological implications of summer fog decline in the coast redwood region. Proceedings of the National Academy of Sciences.

Jones, P.D., Jonsson, T. and Wheeler, D. (1997) Extension to the North Atlantic oscillation using early instrumental pressure observations from Gibraltar and south-West Iceland. International Journal of Climatology, 17(13), 1433-1450.

Lorenzo-Lacruz, J., Vicente-Serrano, S.M., López-Moreno, J.I., Morán-Tejeda, E. and Zabalza, J. (2012) Recent trends in Iberian streamflows (1945-2005). Journal of Hydrology, 414-415 (11), 463-475.

Martín-Vide, J. (2002) Aplicación de la clasificación sinóptica automática de Jenkinson y Collison a días de precipitación torrencial en el este de España. In: Zaragoza, J.M.C., Vicente, S.M. and Saz, M.A. (Eds.) La información climática como herramienta de gestión ambiental. Zaragoza: University of Zaragoza, pp. 123-127.

Martín-Vide, J. and Fernández-Belmonte, D. (2001) El índice NAO y la precipitación mensual en la España peninsular. Investigaciones Geográficas, 26, 41-58.

Martín-Vide, J. and López-Bustins, J.A. (2006) The Western Mediterranean oscillation and rainfall in the Iberian Peninsula. International Journal of Climatology, 26(11), 1455-1475.

Martín-Vide, J. and Olcina Cantos, J. (2001) Climas y tiempos de España. Madrid: Alianza Editorial, S.A.

Marzol, M.V. (2005) La captación del agua de niebla en la isla de Tenerife. Tenerife: Caja General de Ahorros de Canarias.

Marzol, M.V., Sánchez-Megía, J. and Yanes, A. (2011) Meteorological patterns and fog water collection in Morocco and the Canary Islands. Erdkunde, 65(3), 291-303.

Millán, M., Estrela, M.J. and Miró, J. (2005b) Rainfall components: variability and spatial distribution in a mediterranean area (Valencia region). Journal of Climate, 18, 2682-2705.

Millán, M., Estrela, M.J., Sanz, M.J., Mantilla, E., Martin, M., Pastor, F., Salvador, R., Vallejo, R., Alonso, L., Gangoiti, G., Ilardia, J.L. and Navazo, M. (2005a) Climatic feedbacks and desertification: the Mediterranean model. Journal of Climate, 18, 684-701.

Millán, M., Estrela, M.J. and Vallejo, R. (1998) Evaluation of the hydrological inputs in the Mediterranean basin. In: Schemenauer, R.S. and Bridgman, H. (Eds.) Proceedings of the First International Conference on Fog and Fog Collection. Vancouver, Canada. July 19-24, 1998. Ottawa: International Development Research Centre, pp. 281-284.

Miró, J.J., Caselles, V. and Estrela, M.J. (2017) Multiple imputation of rainfall missing data in the Iberian Mediterranean context. Atmospheric Research, 197, 313-330.

Montón Chiva, E. and Quereda Sala, J. (1997) ¿Hacia un cambio climático? La evolución del clima mediterráneo desde el siglo XIX. Fundación Dávalos-Fletcher: Castellón.

Muhlbauer, S., Costa, A.C. and Caetano, M. (2013) The influence of north atlantic oscillation on local drought occurrences in the Iberian peninsula using the vegetation temperature condition index. 13th International Multidisciplinary Scientific Geoconference and EXPO, SGEM 2013, Albena; Bulgaria. pp. 903-912. 
Nyaga, J., Neff, J. and Cramer, M. (2015) The contribution of occult precipitation to nutrient deposition on the west coast of South Africa. PLoS One, 10(5), e0126225.

Olivier, J. and de Rautenbach, C.J. (2002) The implementation of fog water collection systems in South Africa. Atmospheric Research, 64(1-4), 227-238.

Palutikof, J. (2003) Analysis of Mediterranean climate data: measured and Modelled. In: Bolle, H.J. (Ed.) Mediterranean Climate. Berlin: Springer, pp. 125-132.

Pasho, E., Camarero, J.J., De Luis, M. and Vicente-Serrano, S.M. (2011) Impacts of drought at different time scales on forest growth across a wide climatic gradient in North-Eastern Spain. Agricultural and Forest Meteorology, 151(12), 1800-1811.

Peñarrocha, D. (1994) Precipitacions: volums I distribució espacial. In: Pérez Cueva, A. (Ed.) Atlas climàtic de la Comunitat Valenciana (1961-1990). Valencia: Generalitat Valenciana, pp. 86-89.

Quereda Sala, J., Gil Olcina, A., Perez Cueva, A., Olcina Cantos, J., Rico Amoros, A. and Montón Chiva, E. (2000) Climatic warming in the Spanish Mediterranean: natural trend or urban effect. Climatic Change, 46(4), 473-483.

Ramis, C., Homar, V., Amengual, A., Romero, R. and Alonso, S. (2013) Daily precipitation records over mainland Spain and the Balearic Islands. Natural Hazards and Earth System Sciences, 13(10), 2483-2491.

Rasilla, D., García, J.C. and Garmendia, C. (2002) Los temporales de viento: propuesta metodológica para el análisis de un fenómeno infravalorado. In: Cuadrat, J.M., VicenteSerrano, S.M. and Saz, M.A. (Eds.) La información climática como herramienta de gestión ambiental: bases de datos y tratamiento de series climatológicas. Reunión Nacional de Climatología. Albarracín: Universidad de Zaragoza, pp. 129-136.

Revuelto, J., López, J.I., Morán, E., Fassnacht, S. and Vicente, S.M. (2012) Variabilidad interanual del manto de nieve en el pirineo: tendencias observadas y su relación con índices de teleconexión durante el periodo 1985-2011. $8^{\circ}$ Congreso Internacional de la Asociación Española de Climatología. Cambio climático. Extremos e impactos. Salamanca, 25-28 septiembre 2012.

Schemenauer, R.S. and Cereceda, P. (1994) Fog collection's role in water planning for developing countries. Natural Resources Forum, 18(2), 91-100.
Trenberth, K.E. and Paolino, D.A., Jr. (1980) The northern Hemisphere Sea-level pressure data set: trends, errors and discontinuities. Monthly Weather Review, 108(7), 855-872.

Tsimplis, M.N. and Shaw, A.G.P. (2010) Seasonal sea level extremes in the Mediterranean Sea and at the Atlantic European coasts. Natural Hazards and Earth System Science, 10(7), 1457-1475.

Valiente, J.A., Estrela, M.J., Corell, D., Fuentes, D. and Valdecantos, A. (2011) Fog water collection and reforestation at a mountain location in a western Mediterranean basin region: airmass origins and synoptic analysis. Erdkunde, 65(3), 277-290.

Van Heerden, J., Olivier, J. and Van Schalkwyk, L. (2010) Fog water systems in South Africa: an update. In: Proceeding of 5th International Conference on Fog, Fog Collection and Dew 25-30 Julio 2010. Münster: University of Münster, p. 160.

Van Schalkwyk, L. (2011) Fog forescasting at Cape Town Internacional airport: a climatological approach. Universidad de Petroria. Tesiss.

Van Schalkwyk, L. and Dyson, L. (2013) Climatological characteristics of fog at Cape Town international airport. Weather and Forecasting, 28(3), 631-646.

Vicente-Serrano, S.M. (2004) Evolución espacio-temporal de las sequías en el sector central del valle del Ebro: causas y consecuencias ambientales. Universidad de Zaragoza. Tesis.

Vicente-Serrano, S.M., Cabello, D., Tomás-Burguera, M., MartínHernández, N., Beguería, S., Azorin-Molina, C. and El Kenawy, A. (2015) Drought variability and land degradation in semiarid regions: assessment using remote sensing data and drought indices (1982-2011). Remote Sensing, 7(4), 4391-4423.

Vicente-Serrano, S.M. and Trigo, R.M. (2011) Hydrological, Socioeconomic and Ecological Impacts of the North Atlantic Oscillation in the Mediterranean Region. New York: Springer.

How to cite this article: Corell D, Estrela MJ, Valiente JA, Azorin-Molina C, Chen D. Influences of synoptic situation and teleconnections on fogwater collection in the Mediterranean Iberian Peninsula, 2003-2012. Int J Climatol. 2019;1-21. https://doi.org/10.1002/joc.6398 